\title{
50 Common Native Plants Important In Florida's Ethnobotanical History ${ }^{1}$
}

\author{
Ginger M. Allen, Michael D. Bond, and Martin B. Main²
}

\section{Introduction}

Ethnobotany was probably first coined as a term in 1895 by one of Florida's early botanists, John Harshberger, and describes the study of the interaction between people, plants, and culture (Harshberger 1895). There are many components to ethnobotany, including food, fibre, medicine, shelter, fishing and hunting, religion, mythology, magic, and others.

In this document we provide an introduction to ethnobotany in Florida and brief insight into the historical importance of some of Florida's plants to humans. We hope this document inspires readers to further investigate their region's ethnobotanical history. This information is not intended as a guide to using plants for medicinal or other purposes. Readers are warned that some of the most potent poisons known are derived directly from plants and that alleged ethnobotanical uses may be based on unsubstantiated information. Further, the use of plants for medicinal or other purposes may not be safe without proper preparation or dosage, and potential allergic reactions or illness caused by interactions with prescribed medications cannot be predicted. Note: these warnings should be provided as part of any educational program.

Additionally, we provide a non-technical catalog of 50 common plants that have played an important role in Florida's ethnobotanical history (Table 3). Plants included on the list are considered native or naturalized, are easy to locate and identify, and have interesting histories that lend themselves to teaching others about practical implications of Florida's plant communities. Plant names and status follow descriptions by Missouri Botanical Gardens, Wunderlin et al. (2000), and the Florida Native Plant Society.

\section{Ethnobotany in Florida}

Plants create their own chemical components that may be used to attract or repel insects and animals, attack other plants, or defend against fungi and other plant pathogens. For humans, these chemical components may be nutritious, poisonous, hallucinogenic, or therapeutic. Humans have been accumulating knowledge of plants and their uses for thousands of years. The first recorded culturally significant plant remains were found in Iraq at a human burial site estimated at 60,000 years old.

1. This document is Circular 1439, one of a series of the Wildlife Ecology and Conservation Department, Florida Cooperative Extension Service, Institute of Food and Agricultural Sciences, University of Florida. Published: December 2002. Please visit the EDIS Web site at http://edis.ifas.ufl.edu.

2. Ginger M. Allen, senior wildlife biological scientist, and Martin B Main, Ph.D., associate professor and extension wildlife specialist, University of Florida, Southwest Florida REC, Immokalee, FL 34142. Michael Bond, Graduate student, Department of Soil and Water Sciences, 2169 McCarty Hall, University of Florida, Gainesville FL 32611

The Institute of Food and Agricultural Sciences is an equal opportunity/affirmative action employer authorized to provide research, educational information and other services only to individuals and institutions that function without regard to race, color, sex, age, handicap, or national origin. For information on obtaining other extension publications, contact your county Cooperative Extension Service office. Florida Cooperative Extension Service/Institute of Food and Agricultural Sciences/University of Florida/Christine Taylor Waddill, Dean. 
Many plants provided important sources of food for Native Americans and early settlers in Florida. Important food plants included fruits, nuts, roots (starch), grains, and greens that varied by habitat, region, and time of year. A few examples of important food plants included fruits from cocoplum (Chrysobalanus icaco), pond apple (Annona glabra), and saw palmetto (Serenoa repens); and starch from coontie (Zamia pumila) roots (see Table 3 ). The "heart" of the cabbage palm (Sabal palmetto), commonly referred to as swamp cabbage, was and still is commonly eaten in many rural areas (see Table 3). Generally speaking, ethnobotanical uses of plants can be grouped into six main applications: food, fiber (including dyes), medicinal, housing/construction materials, transportation, and miscellaneous uses (tools, toys, weapons, ceremonial objects, etc.).

In what is now the southeastern United States including Florida, evidence indicates indigenous tribes traded or exchanged goods throughout eastern North America. Glades Indians were Florida's indigenous people, whose tribes included the Calusa (southwest Florida), Tequesta (southeast Florida), Mayamis (Lake Okeechobee), and lesser known Jaega and Ais (Austin, 1997). During the Mississippian Culture Period (1000 to 1700 A.D.), the transfer of goods continued and these uses began to be better documented, which provided information currently available about plants and their uses. Spanish explorers, missionaries, and settlers also brought new plants and information to Florida.

Native American peoples who lived in Florida at the time of European settlement were decimated as a result of introduced diseases, forced labor, physical conflicts, and other factors. As a result, information on native plant species and how they were used was undoubtedly lost or destroyed. Paleoethnobotanists study the use of plants by humans based on archaeological information and have restored some of that lost information, including information about early people's diets, class structure, gender relations, and site structure. Additionally, paleoethnobotanists have learned that plants used in Florida vary in distinct ways from trends found at sites in other southeastern states. For example, evidence from south Florida indicates the use of sub-tropical plants such as papaya (Carica papaya; D. Ruhl, Florida Museum of Natural History, pers. comm., 2001). In Florida's northern panhandle, prehistoric finds show only a few pockets containing southern plant species found at sites in Georgia, Alabama, and further north (e.g., Fritz 1993; Ruhl 2000). Florida sites lacked many of the starchy plants and contained different species of nuts as compared to more northern locations.

Today's Florida Seminole and Mikasuki tribes, although not indigenous Florida peoples, still use traditional herbal remedies passed down by their ancestors. For the majority of Florida's current population, dependence on gathering native plants for food has been replaced by commercial agriculture.

Native plants that have been developed into significant commercial crops include pecans (Carya illinoiensis), blueberries (Vaccinium sp.), and muscadine grapes (Vitis rotundifolia)(see Table 3 ). Citrus (Citrus sp.), which was first introduced by the Spanish during the 1500 s, currently is one of Florida's most important commercial commodities (Jackson \& Davies 1999).

Fiber from various plants was used for many purposes, such as cordage (rope), baskets, clothing, and other everyday materials. Palms were an important source of fiber and construction material for shelters. Other fiber sources included grasses such as wire grass (Aristida beyrichiana) and switch grass (Schiachyrium tenerum), broadleafed plants such as Indian hemp (Apocynum cannabinum), and the bark of trees such as mahoe (Hibiscus tiliaceous) and strangler fig (Ficus auraurea)(see Table 3).

Dyes played important roles in Native American life, just as they do in modern times. Dyes were used in coloring textiles, in craftwork (pottery, basketry) and in ceremonies (face paints, objects). Table 1 provides a list of native plants used as sources of dyes and their fixatives (mordants), which are used to enhance dye color and duration.

Perhaps one of the most intriguing aspects of ethnobotany is the use of native plants for religious and medicinal purposes. Attempted replication of traditional herbal remedies is neither straightforward nor advisable. Many traditional herbal medicines are complex mixtures of different plant parts that must 
be gathered and prepared at different times of the year, mixed in specific proportions, and administered in scheduled doses of particular size and dilution. Traditional herbal remedies often include religious components and rituals that represent important links between past and present culture (Giese, 1995). Learning to prepare traditional Native American medicines properly may be problematic, because remedies typically are learned only through personal instruction during an apprenticeship with a medicine person. Although traditional herbal medicines have provided the basis for many modern pharmaceuticals and herbal remedies, many traditional medicines may be based on superstition. For example, some medicines are predicated on the similarity between a plant part and a human organ, such as the use of walnuts (Juglans nigra) to treat brain disorders.

Today, herbal remedies, many of which are based on ethnobotanical information, are receiving renewed interest in the United States, although they are still much less used in the United States than in other parts of the world. The World Health Organization (1985) estimated that $80 \%$ of the world's population uses herbal medicine for some aspect of primary health care. Herbal remedies, by definition, are therapeutic compounds that occur naturally in plants. In the United States, herbal remedies are classified as nutritional supplements rather than drugs because most companies that supply herbal remedies either cannot or choose not to pay for the extensive clinical testing required for drug efficacy by the U.S. Food and Drug Administration (USFDA). Companies that market herbal remedies, therefore, choose to identify them under the label of nutritional supplements, which are not subject to product guarantees on safety or constituents. The lack of clinical testing afforded nutritional supplements warrants caution by persons seeking to use herbal products for medicinal remedies. In recognition of these risks, the USFDA has recently begun a central registry for deaths and injuries caused by the ingestion of herbal supplements.

Ethnobotanical information has also been proven important for the development of modern pharmaceuticals. Estimates have suggested that as much as one half of the popular pharmaceuticals employed today have ethnobotanical origins. To date, there are approximately 120 plant-based prescription drugs (95 different species) on the U.S. market. Florida's saw palmetto berries have been harvested, and commercial use/production has been heightened with the recent knowledge that saw palmetto has been associated with treating prostate cancer and other maladies of this gland. In general, chemicals that have medical properties can be summarized into 7 broad categories: alkaloids, glycosides and related compounds, phenols, organic acids, resins and gums, saponins, and essential oils (Table 2).

\section{Ethnobotany and the Future}

Native plants represent a tremendous natural resource with potential for new medicines, food crops, and varieties, as well as other products. Unfortunately, the cost of research, development, and testing, particularly for pharmaceuticals, has slowed the pace of development of new plant products. For example, only about $10 \%$ of the more than 250,000 known species of plants have been screened in laboratories to determine their therapeutic potential (Kinghorn 1994). Although the search for new plant compounds that provide medicinal and other uses continues throughout the world, particularly in the major rain forests (Asia, Africa, and the Amazon), rain forest deforestation and the rapid destruction of other areas of high biological diversity may eliminate many opportunities for new discoveries.

Many opportunities for plant research and expansion still exist in Florida. Recent activities, such as the marketing of saw palmetto fruits to reduce swelling associated with prostate cancer and the discovery that mayapple (Podophyllum peltatum) is the source of a compound used in cancer chemotherapy (etopiside), provide examples of valuable discoveries with substantial economic returns. The mayapple harvest in Florida during 1993 was estimated to be worth $\$ 350$ million, and the Florida palmetto crop export business is estimated at $\$ 50$ million a year .

Although discovery opportunities still exist, rapid loss of natural habitats and alteration of native plant communities by invasive exotic plants and human encroachment threaten Florida's natural areas and compromise the potential of future findings. 
There are currently more than 300 plants listed on the state endangered species list in Florida. As native plants disappear, so does opportunity for ethnobotanical uses. Our objective is to provide a brief sampling of ethnobotanical information, in the hopes of generating interest and greater appreciation for the important roles that plants have played in human history, as well as the potential for future discoveries. To facilitate this effort, we have listed 50 common plants, their descriptions, 26 photo plate images and information regarding their ethnobotanical history in Florida (Table 3).

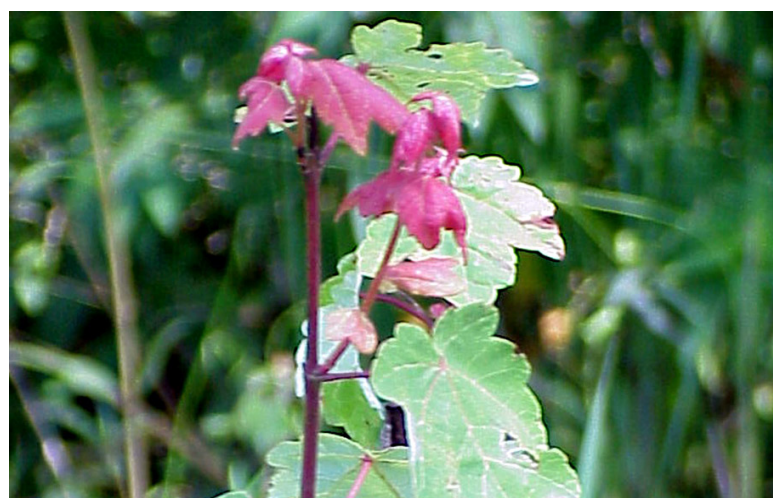

Plate 1. Red Maple. Photo by G. Allen.

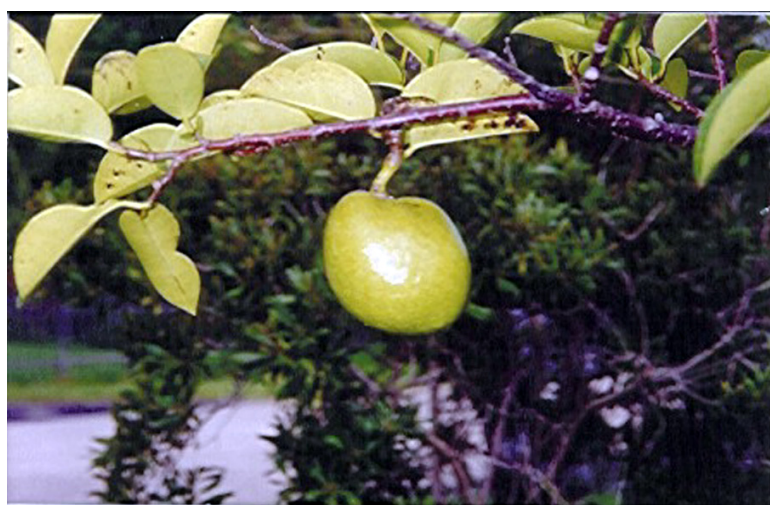

Plate 2. Pond-apple. Photo and permission to use by S.F.W.M.D.

\section{Sources of Information}

Atlas of Florida Vascular Plants. Online: http://www.usf.edu/ isb/projects/atlas/atlashtml.

Austin, D. F. 1997. Glades Indians and the Plants they Used. The Palmetto17:7-11.

Balick, M., and P. Cox. 1997. Plants, People, and Culture: The Science of Ethnobotany. W.H. Freeman Co, New York, N.Y. 256pp.

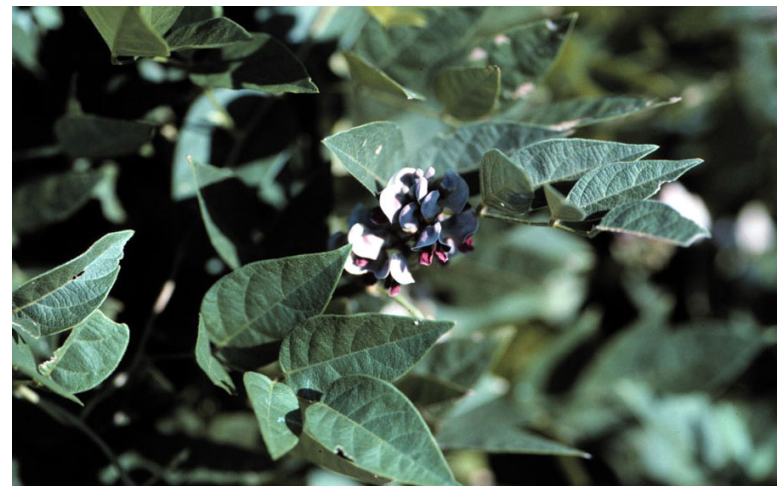

Plate 3. American Groundnut. Photo and permission to use by L. Allain.

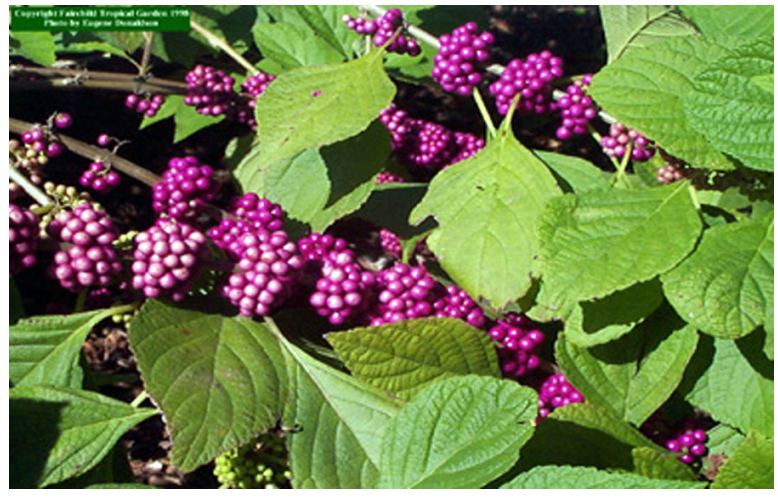

Plate 4. Beautyberry. Photo and permission to use by G.F. Guala.

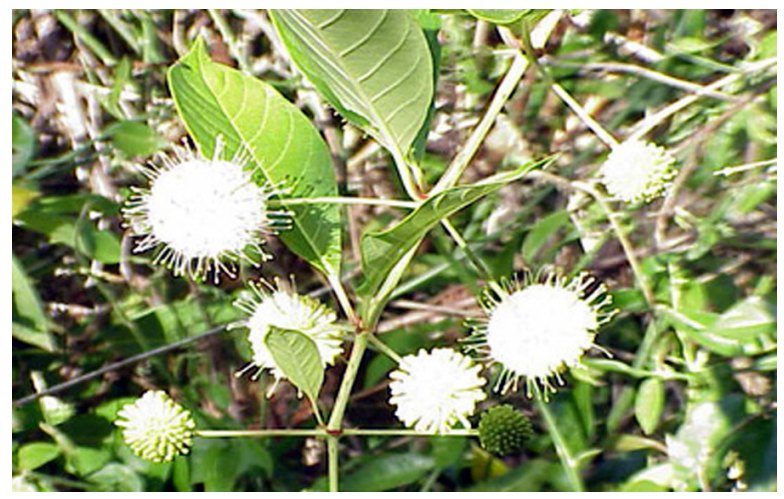

Plate 5. Buttonbush. Photo by G. McAvoy.

Bartram, J., and W. Bartram. 1957. John and William Bartrams' America: Selections from the writings of the Philadelphia Naturalists. The Devin-Adair Company, New York, N.Y. 418pp.

Bennett, B. C. 1997. An introduction to the Seminole people and their plants, Part I: History and Ethnology. The Palmetto17:20-24.

Bennett, B.C. 1997. An introduction to the Seminole people and their plants, Part II: Seminole plant use. The Palmetto 17:16-22. 


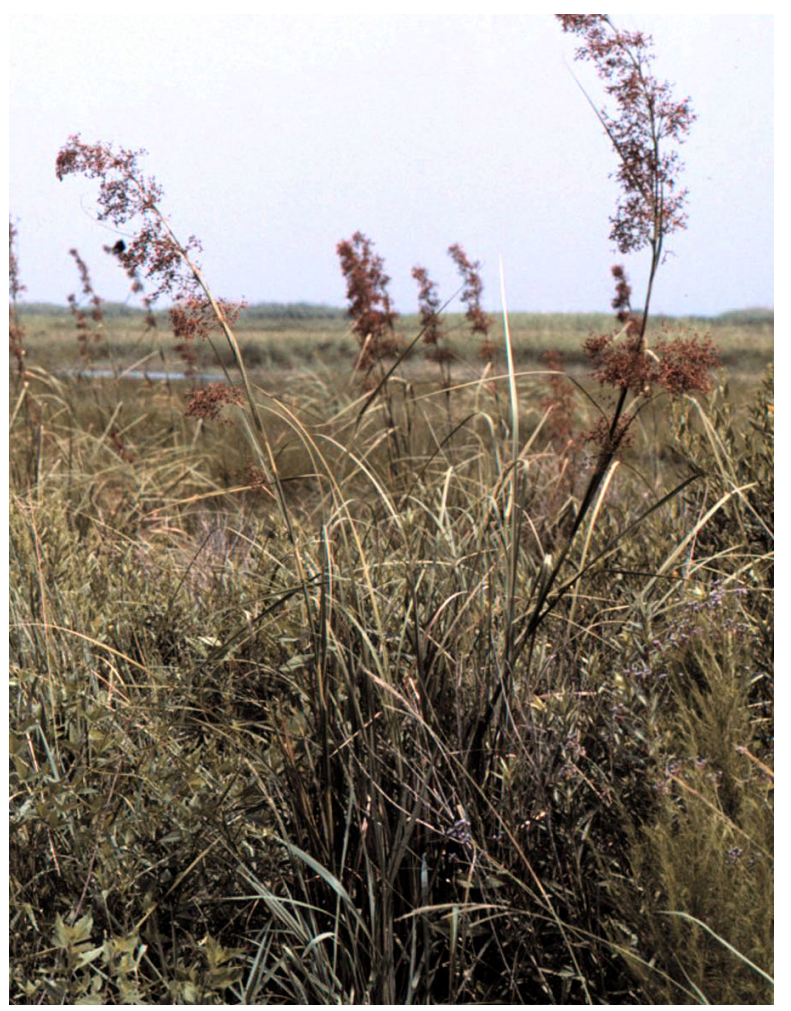

Plate 6. Sawgrass. Photo and permission to use by L. Allain.

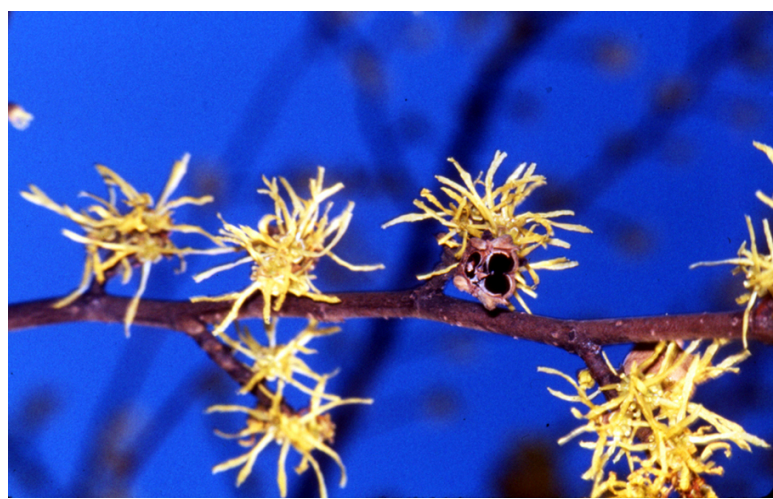

Plate 7. Witch-hazel. Photo and permission to use by K. Robertson.

Duke, J. A. 2000. Phytochemical Database, USDA-ARS, Beltsville Agricultural Research Center, Beltsville, MD. Online: www.ars-grin.gov/duke/.

Florida Native Plant Society. Online: HYPERLINK http://www.fnps.org/.

Foster, S., and J. A. Duke. 2000. A Field Guide to Medicinal Plants and Herbs of Eastern and Central North America, The Peterson Field Guide Series. Houghton Mifflin Co, Boston, MA, 411pp.

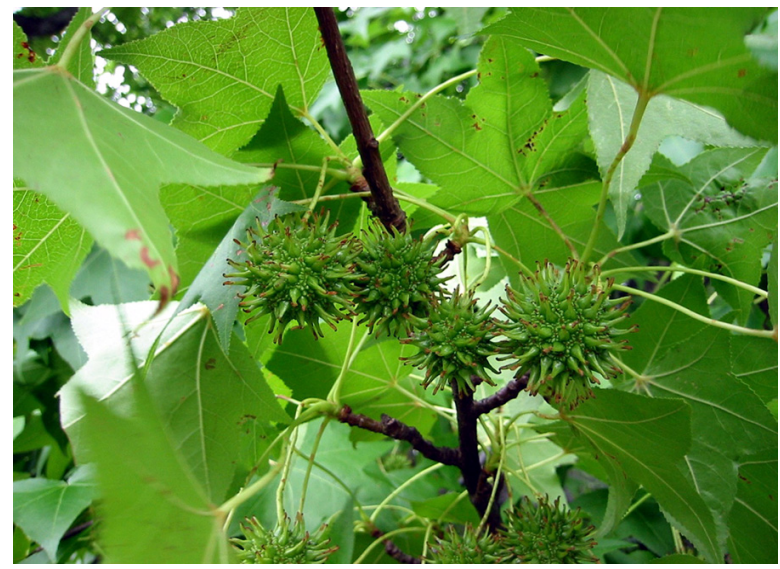

Plate 8. Sweet Gum, Red Gum. Photo and permission to use by J.S. Peterson.

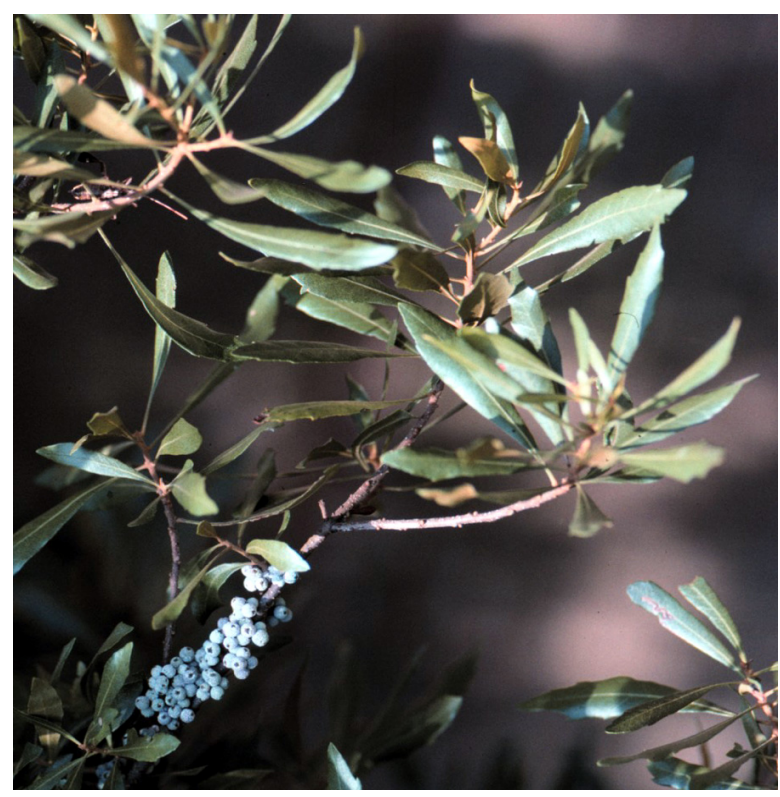

Plate 9. Wax-myrtle. Photo and permission to use by L. Allain.

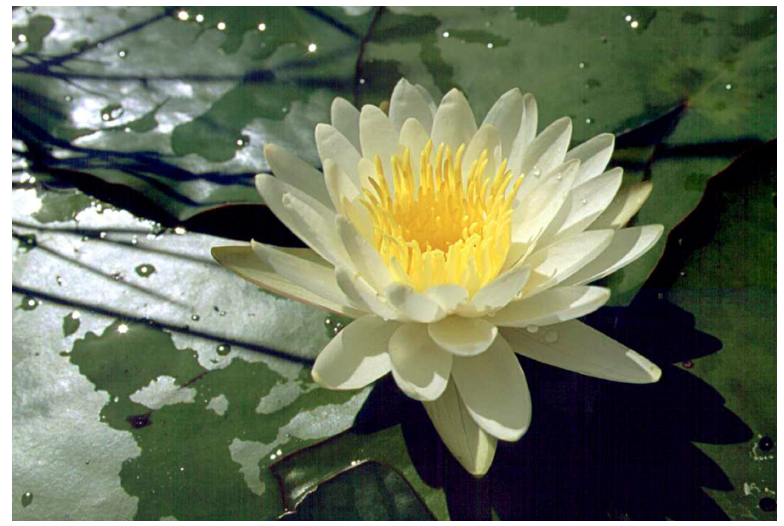

Plate 10. White Water-lily. Photo and permission to use by S.F.W.M.D.

Fritz, G. 1993. Early and Middle Woodland Period Paleoethnobotany. In Foraging and Farming 


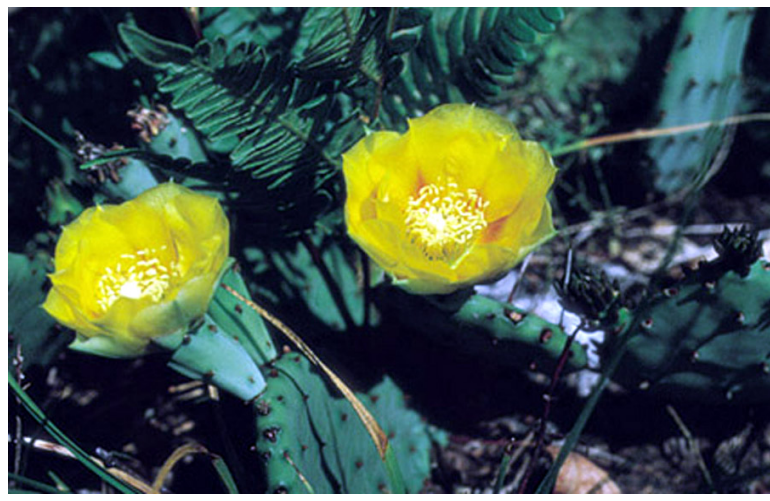

Plate 11. Prickly-pear. Photo and permission to use by S. Sutherland.

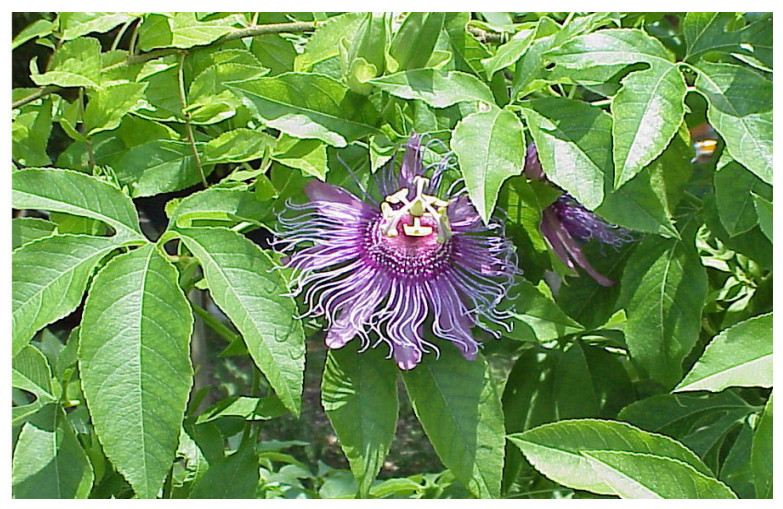

Plate 12. Purple Passion flower. Photo by G. Allen.

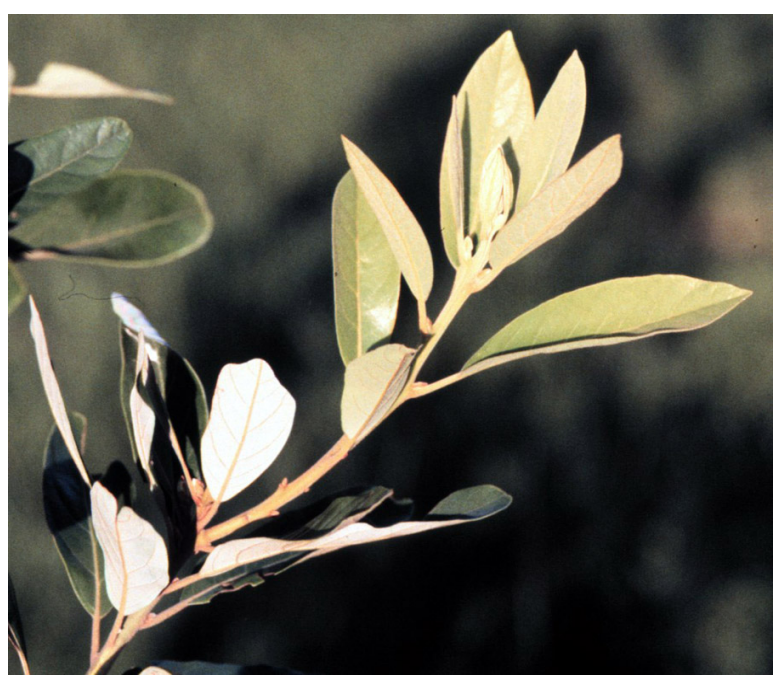

Plate 13. Red-bay, Swamp-bay. Photo and permission to use by L. Allain.

in the Eastern Woodlands, edited by C. Scarry, pp. 39-56. University Press of Florida, Gainesville, FL.

Giese, P. 1995. Traditional Herbal \& Plant Knowledge.

Online:www.kstrom.net/isk/food/plants.html.

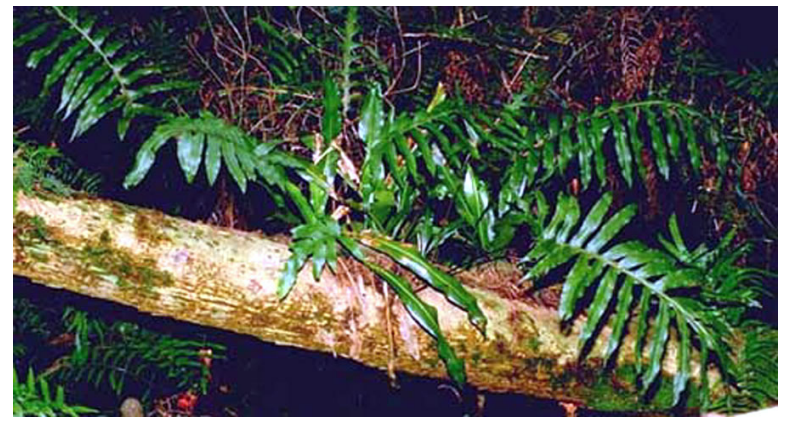

Plate 14. Golden Polypody, Goldenfoot Fern. Photo by D. Scofield.

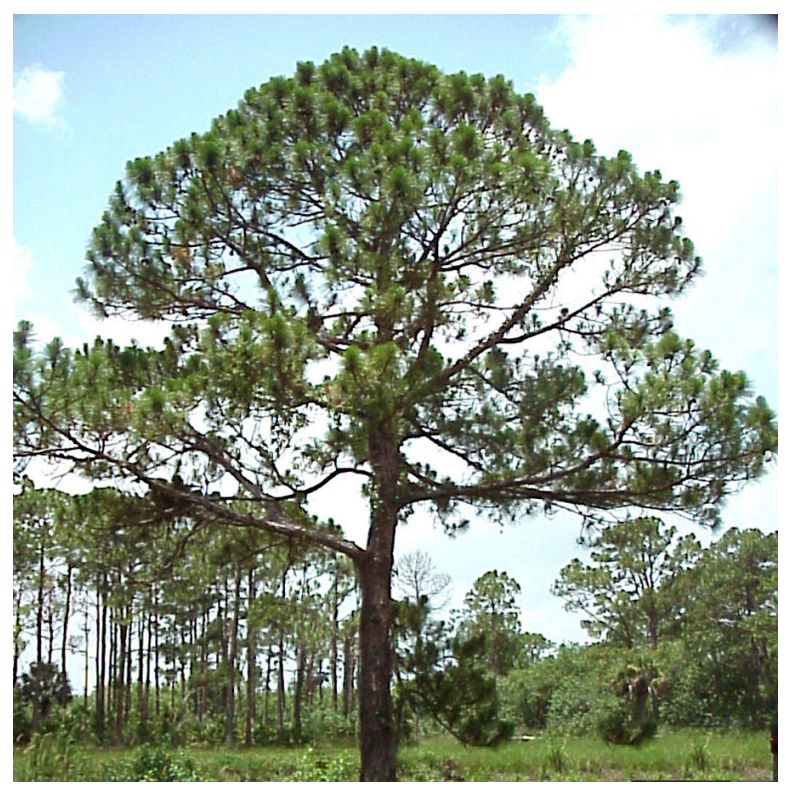

Plate 15. Slash Pine. Photo by G. Allen.

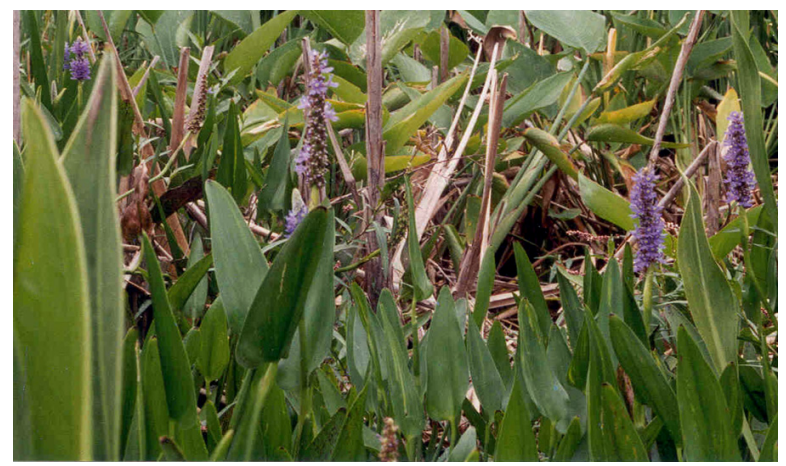

Plate 16. Pickerelweed. Photo by G. Allen.

Godfrey, R. and J. Wooten. 1981. Aquatic and Wetland Plants of the Southeastern United States. Dicotyledens and Monocotyledens. The University of Georgia Press, Athens, GA. 712pp.

Harshberger, J. W. 1895. The Purposes of Ethno-botany, Publication FF12, University of Pennsylvania Archives and Records Center, Philadelphia, PA. 


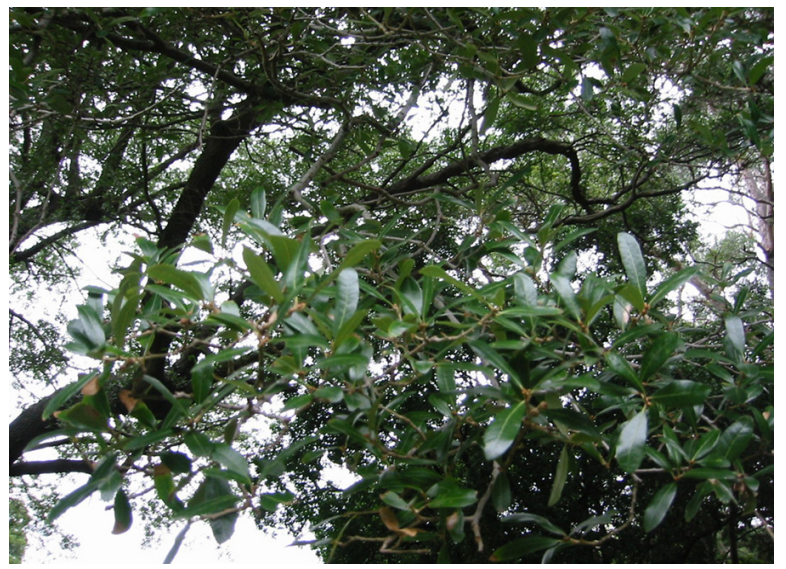

Plate 17. Live Oak. Photo and permission to use by J.S. Peterson.

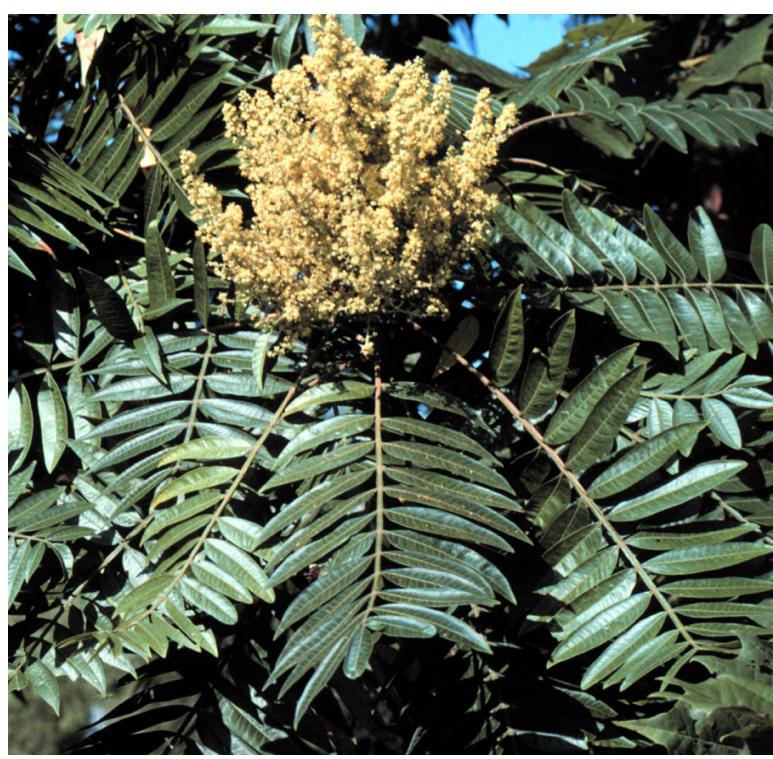

Plate 18. Winged Sumac. Photo and permission to use by L. Allain.

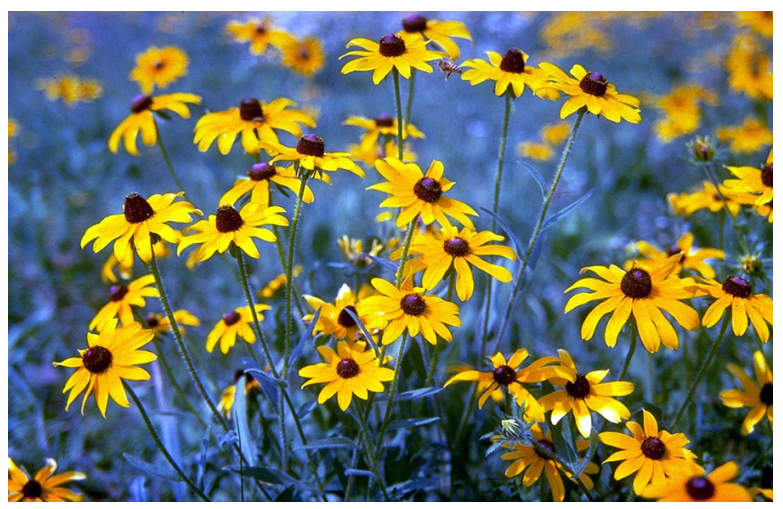

Plate 19. Black-eyed Susan. Photo by M. van der Grinten.

Jackson, L.K. and F.S. Davies 1999. Citrus Growing in Florida. University Press of Florida, Gainesville, FL. 408pp.

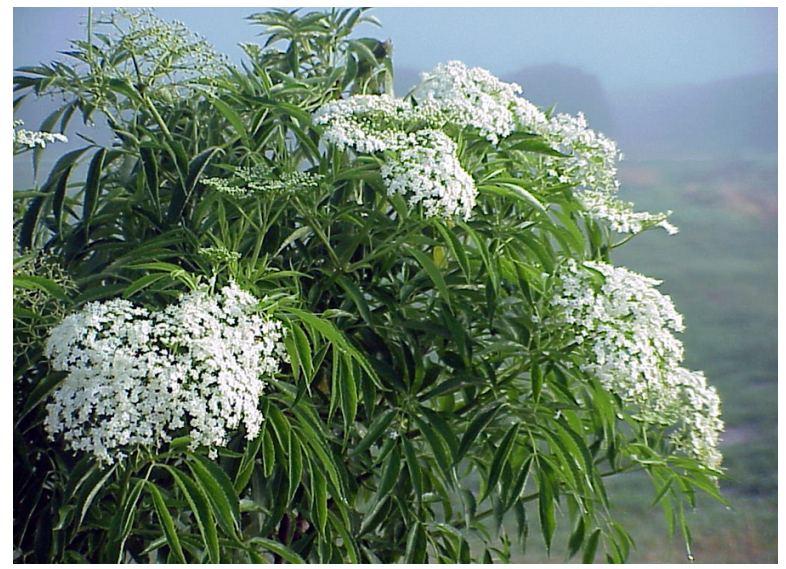

Plate 20. Elderberry. Photo by G. Allen.

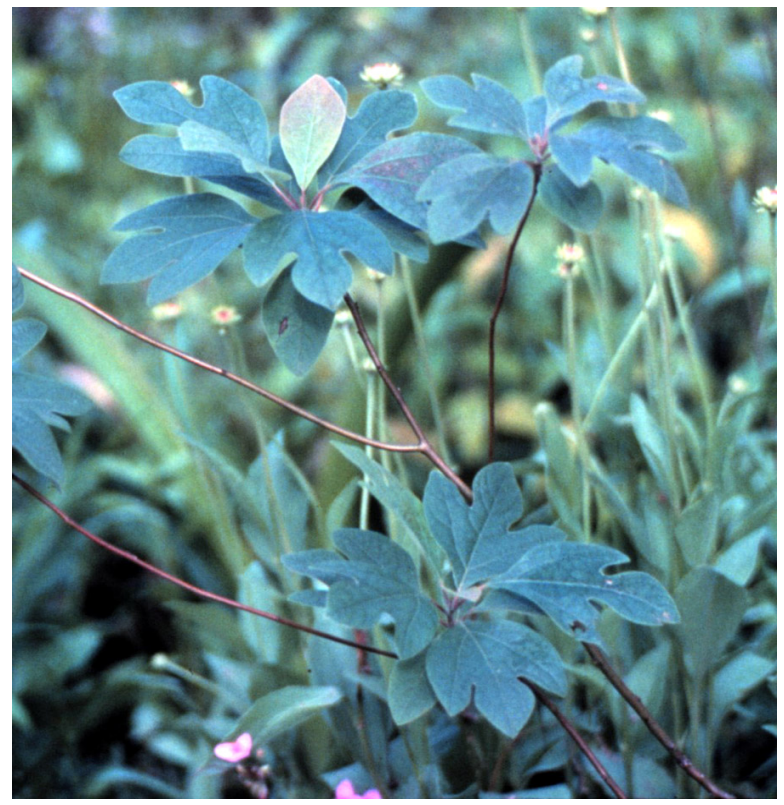

Plate 21. Sassafras. Photo and permission to use by $L$. Allain.

Jensen, T. (out of print) Living Off The Land In Florida, Forest Resources and Conservation Fact Sheet, University of Florida, IFAS, Gainesville, FL, $4 \mathrm{pp}$.

Kinghorn, A. D. 1994. The Discovery of Drugs from Higher Plants, in The Discovery of Natural Products with Therapeutic Potential, ed. V.P. Gullo, Butterworth-Heineman, Boston, MA. 97pp.

Lampe, K. F. and M. A. McCann. 1985. AMA Handbook of Poisonous \& Injurious Plants. American Medical Association, Chicago Review Press, Chicago, IL. 432pp.

Mattus, R. 1999. Impact of cypress harvesting studied. The Gainesville Sun, Gainesville, FL. 


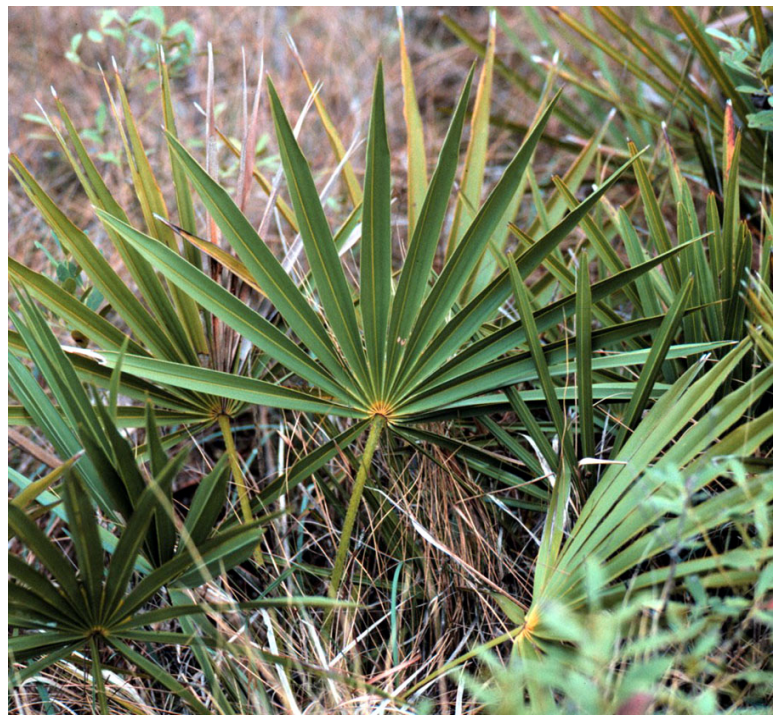

Plate 22. Saw Palmetto. Photo and permission to use by L. Korhnak.

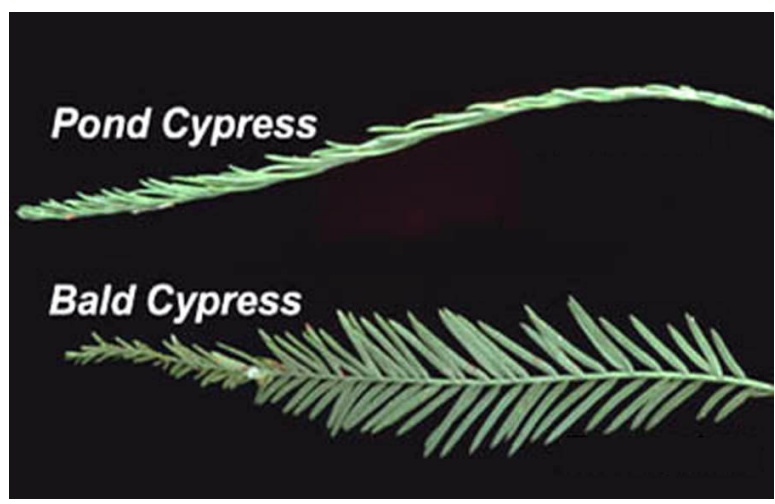

Plate 23. Pond/Bald Cypress branches. Photo by C. Hunter.

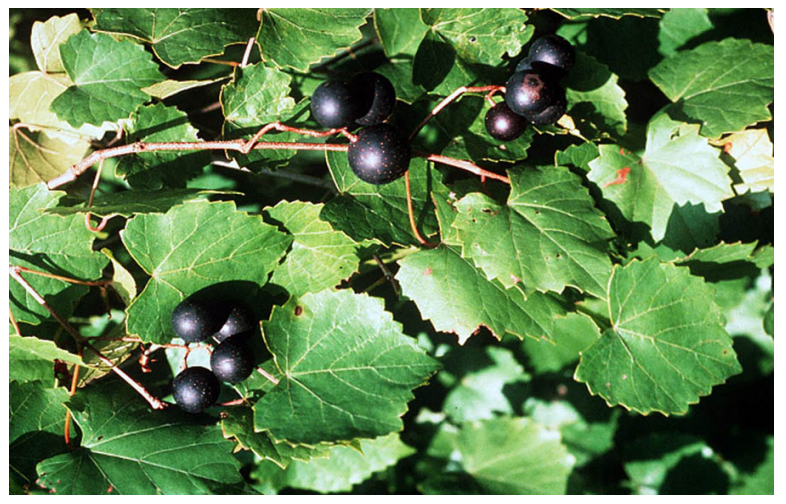

Plate 24. Muscadine Grape Scuppermong. Photo and permission to use by G.F. Guala.

Online:

http://www.sunone.com/news/articles/02-2099f.shtml.

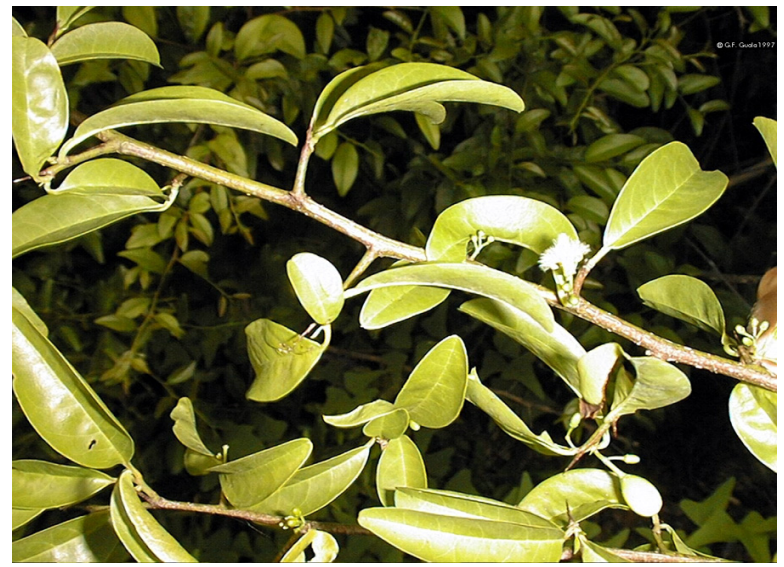

Plate 25. Tallow-wood. Photo by G.F. Guala.

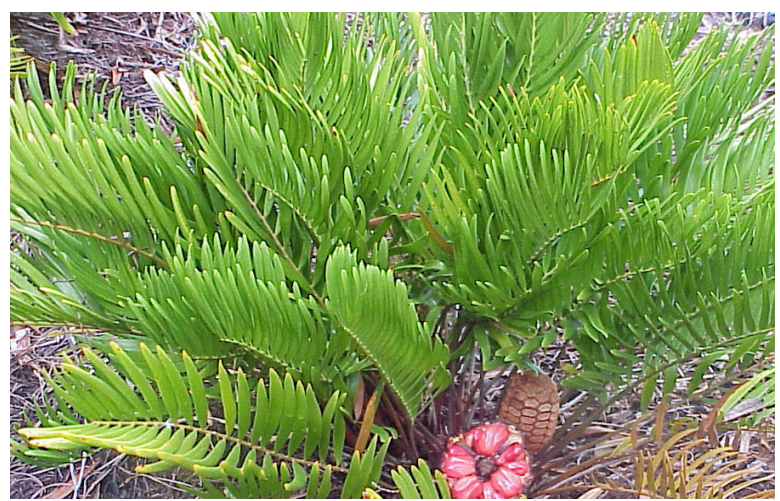

Plate 26. Coontie. Photo by G. Allen.

Mendosa, R. 1999, Saw Palmetto for Benign Prostatic Hyperplasia (BPH). Online:

http://www.mendosa.com/sawpalm.htm.

Missouri Botanical Gardens Vascular Tropicos Nomenclatural Database. Online: http://mobot.mobot.org/W3T/Search/vast.html.

Mitich, L. W. 2000. Intriguing World of Weeds. Univ. of California, Davis. Online: http://ext.agn.uiuc.edu/extension/weeds/ CDWFS.htm.

Moerman, D. E. 1998. Native American Ethnobotany. Timber Press, Portland, OR. 927pp.

Morton, J. 1962. Wild Plants For Survival in South Florida. Hurricane House, Miami, FL. 79pp.

Morton, J. 1974. 500 Plants of South Florida. E.A. Seemann Publishing, Inc., Miami, FL. 163pp.

Moyers, S. B. 1997. Medicinal Plants of Florida. The Palmetto 17:12-15. 
Newsom, L. A. and C. M. Scarry. (In preparation). Home Gardens and Mangrove Swamps: Pineland Archaeobotanical Research. Chapter 6 in The Archaeology of Pineland: A Coastal Southwest Florida Village Complex, edited by K. Walker and W. Marquardt.

Peterson, L. A. 1977. A Field Guide to Edible Wild Plants Eastern and Central North America, The Peterson Field Guide Series. Houghton Mifflin Company, Boston, MA, 330pp.

Ruhl, D. L. 2000. Archaeobotany at Bernath Place (8SR986) and other Santa Rosa/Swift Creek-Related Sites in Coastal and Non-coastal U.S. Locations. Florida Anthropologist 53:190-202.

Ruhl, D. L. 2002. Chapter 8-Archaeobotanical Investigations of Selected Samples from Remnant Mound. In Archaeological Investigations of De Soto National Memorial, by Margo Schwadron, pp. 139-157, 262-274. SEAC Technical Reports No. 8, Southeast Archeological Center, National Park Service, Tallahassee.

Smith, E. 1993. Natural Dyes from Florida Native Plants. The Palmetto 13:12-15.

Snow, A. M., and S. E. Stans. 2001. Healing Plants: Medicine of the Florida Seminole Indians. University Press of Florida, Gainesville, FL. 134 pp.

Solecki, R. 1975. Shanidar IV, A Neanderthal Flower burial in Northern Iraq. Science 190:880-881.

Stephens, J. M. 1998. Herbs in the Florida Garden. Florida Cooperative Extension Service. Circular 570.7p.

Sturtevant, W. C. 1954. The Mikasuki Seminole Medical Beliefs and Practices. Ph.D. Thesis, Department of Anthropology, Yale University, Sterling Memorial Library, microform, 68pp.

Tanner, G. W., Mullahey J. J. and D. Maehr 1996. Saw-palmetto: an Ecologically and Economically Important Native Palm. Florida Cooperative Extension Service. Circular WEC109. 4p. Online at: http://edis.ifas.ufl.edu.
Tyler, V. E., L. R Brady, and J. E. Robbers. 1988. Pharmacognasy. Lea and Febiger, Philadelphia, PA, 519pp.

USDA, NRCS 1999. The PLANTS database http://plants.usda.gov/plants National Plant Data Center, Baton Rouge, LA 70874-4490 USA.

Workman, D. 1980. Growing Native: native plants for landscape use in coastal south Florida. The Sanibel-Captiva Conservation Foundation, Sanibel, FL, 137 pp.

Workman, D. 1995. Primitive Technology or Marking Do with Native Plants. The Palmetto 15:6-8.

World Health Organization. 1985. WHO/DANIDA Training Course: the Selection and Use of Traditional Remedies in Primary Health Care. (Report of an Inter-Regional Workshop held in Bangkok, Thailand, 25 November - 4 December 1985), WHO/TRM/86.1, WHO Geneva, 1986.

Wunderlin, R. P., B. F. Hansen, E. L. Bridges and J. B. Fisher. 2000. Flora of Florida. University Press of Florida, Gainesville, FL, 384pp.

Zomlefer, W. 1994. Guide to Flowering Plant Families. Chapel Hill : University of North Carolina Press, Chapel Hill, NC, 430 pp.

\section{Image Plate Credits}

Plates 4, 25. Copyright $\odot$ Guala, G.F. 2001. Fairchild Tropical Garden. www.virtualherbarium.org.

Plates 1, 12, 15, 16, 20, 26. Copyright $($ Allen, G. 2001. University of Florida, IFAS, SWFREC, Wildlife Ecology and Conservation Dept.

Plates 2, 10. South Florida Water Management District Photo Gallery 2003. http://www.sfwmd.gov.

Plates 3, 6, 9, 13, 18, 21, 22. Allain, L. @USDA-NRCS PLANTS Database 2003. http://plants.usda.gov/plants. National Plant Data Center, Baton Rouge, LA, USA.

Plate 5. Copyright $₫$ McAvoy, G. 2001. Hendry County Extension, University of Florida/IFAS. 
Plate 7. Copyright $(\odot$ Robertson, K. Illinois Natural

History Survey, Center for Biodiversity.

www.inhs.uiuc.edu.

Plate 11. Copyright $\odot$ Sutherland, S. Oak

Openings Region

Plate 14. Copyright $\odot$ Scofield, D. 1996-1998.

Native Plants of South Florida.

http://www.cassiakeyensis.com.

Plates 8, 17. Peterson, J.S. @ USDA-NRCS

PLANTS Database 2003.

http://plants.usda.gov/plants. National Plant Data

Center, Baton Rouge, LA, USA.

Plate 19. van der Grinten, M. @ USDA-NRCS

PLANTS Database 2003.

http://plants.usda.gov/plants. National Plant Data

Center, Baton Rouge, LA, USA.

Plate 23. Copyright $@$ Korhnak, L. Florida 4-H

Forest Ecology, School of Forest Resources and

Conservation, University of Florida, Gainesville, www.sfrc.ufl.edu/4h/.

Plate 24.Hunter, C. @ USDA-NRCS PLANTS Database 2003. http://plants.usda.gov/plants.

National Plant Data Center, Baton Rouge, LA, USA. 
Table 1. Dyes obtained from Native Florida Plants ( Adapted from Smith 1993).

\begin{tabular}{|c|c|c|c|c|}
\hline Common & Scientific Name & Plant Part & Fixative & Color \\
\hline Agrimony & Arunibua so. & Leaves, stem & Alum & Brass, Yellow \\
\hline \multirow[t]{2}{*}{ Beach Sunflower } & \multirow[t]{2}{*}{ Helianthus debillis } & Flower & Alum & Pale green \\
\hline & & Seeds & Alum & Purple, Black \\
\hline Betony & Stachys floridanum & Whole Plant & Alum & Chartreuse \\
\hline \multirow[t]{2}{*}{ Coreopsis } & \multirow[t]{2}{*}{ Coreopsis spp. } & Flower & Alum & Yellow \\
\hline & & Whole Plant & Alum & Red \\
\hline Dandelion & Taraxacum officianal & Whole Plant & Alum, tin & Yellow \\
\hline Dock & Rumex sp. & Roots, Leaves & Alum, Chrome & Yellow \\
\hline \multirow[t]{2}{*}{ Elderberry } & \multirow[t]{2}{*}{ Sambucus simpsonii } & Berry & Alum & Rose \\
\hline & & Leaves & Alum & Green \\
\hline Feverfew & $\begin{array}{l}\text { Chrysanthemum } \\
\text { spp. }\end{array}$ & Leaves, Stem & Chrome & Green, Yellow \\
\hline Ficus & Ficus aurea & Berry & Alum & Rose \\
\hline Goldenrod & Solidago spp. & Whole Plant & $\begin{array}{l}\text { Alum,iron/chrome/ } \\
\text { tin }\end{array}$ & Yellow \\
\hline Groundsel & Baccharis spp. & Leaf & Alum & Yellow \\
\hline \multirow[t]{2}{*}{ Live Oak } & \multirow[t]{2}{*}{ Quercus virginiana } & Leaf, Bark & Copper & Gray \\
\hline & & Roots, Bark & Copper & Red \\
\hline Pine Tree & Pinus sp. & Cones & Iron & Brown \\
\hline Pokeweed & $\begin{array}{l}\text { Phytolacca } \\
\text { americana }\end{array}$ & Berry & Alum & Rose \\
\hline Prickly Pear & Opuntia spp. & Fruit & Alum & Peach \\
\hline Red Maple & Acer rubrum & Leaf & Alum & Tan \\
\hline Rouge Plant & Rivina humilis & Berry & Alum & Orange \\
\hline St. John's Wort & Hypercium spp. & Leaf, Flower & Alum & Yellow \\
\hline Spanish Moss & Tillandsia usneoides & Whole Plant & Alum & Tan \\
\hline Walnut & Juglans spp. & Husk & Alum & Rust \\
\hline Wax Myrtle & Myrica cerifera & Leaf & Alum & Yellow \\
\hline Yarrow & Achillea spp. & Whole Plant & Alum, iron & Yellow, Olive \\
\hline
\end{tabular}

Table 2. General classes of chemicals found in plants worldwide and associated medicinal drug uses.

\begin{tabular}{||l|l|l||}
\hline \hline Chemical Class & Value & Plant Example \\
\hline Alkaloids & Stimulant & Coffee (Coffea sp.) \\
\cline { 2 - 3 } & Ophthalmolgy, dilates pupils & Jimson Weed (Datura sp.) \\
\cline { 2 - 3 } & Euphoric & Cocao (Theobroma cacao) \\
\cline { 2 - 3 } & Malaria treatment & Quinine (Cinchona succiruba) \\
\cline { 2 - 3 } & & $\begin{array}{l}\text { Dogwood (Cornus florida), Magnolia } \\
\text { Magnolia grandifloria) }\end{array}$ \\
\cline { 2 - 3 } & Pain relievers & Opium poppy (Papaver somniferum L.) \\
\cline { 2 - 3 } & Pepper flavoring & Cayenne (Capsicum frutescens) \\
\hline
\end{tabular}


Table 2. General classes of chemicals found in plants worldwide and associated medicinal drug uses.

\begin{tabular}{|c|c|c|}
\hline \multirow[t]{5}{*}{ Glycosides and glucosides } & Heart therapy & Digitalis or Foxglove (Digitalis purpurea) \\
\hline & Discourages smoking & Plantain (Plantago major) \\
\hline & $\begin{array}{l}\text { Poison to plant predators, ingested by } \\
\text { Monarch (Danaus plexippus) }\end{array}$ & Milkweed ( Apocynum and rosaemifolium) \\
\hline & Inhibit thyroid functioning & Kale, mustard, cabbage family (Cruciferae). \\
\hline & $\begin{array}{l}\text { Coughs, circulation, tumors, antiseptic, } \\
\text { digestive }\end{array}$ & $\begin{array}{l}\text { Almonds, prunes, apricots, cassava, } \\
\text { Chamomile (Anthemis nobilis) }\end{array}$ \\
\hline \multirow[t]{4}{*}{ Phenols and polyphenols } & $\begin{array}{l}\text { Surgical antiseptics, anticoagulants, } \\
\text { cancer }\end{array}$ & $\begin{array}{l}\text { Cloves, cinnamon,thyme, oregano, Milk } \\
\text { Thistle (Silybum marianum) }\end{array}$ \\
\hline & Anticoagulant & Coumarin (Trifolium patense) \\
\hline & $\begin{array}{l}\text { Mixed with glycosides stimulants, } \\
\text { topical, laxative }\end{array}$ & $\begin{array}{l}\text { Aloe }(\text { Aloe vera) } \\
\text { rhubarb, senna }\end{array}$ \\
\hline & Burns, abrasions, digestive & Whitch hazel (Hamamelis virginiana) \\
\hline \multirow[t]{2}{*}{ Organic acids/esters } & Pain reliever & White willow (Salix sp.) \\
\hline & Plant defense mechanism & Stinging nettle (Utricaria urens) \\
\hline \multirow[t]{3}{*}{ Resins and gums } & \multirow{3}{*}{$\begin{array}{l}\text { Used topically to seal and disinfect } \\
\text { wounds, abrasions and lacerations }\end{array}$} & Pine trees (Pinus sp.) \\
\hline & & Myrhh (Commiphora molmol) \\
\hline & & Storax (Liquidambar sp.) \\
\hline Sapponins & $\begin{array}{l}\text { Stimulant, active anti-inflammatory } \\
\text { hormones, fish poison }\end{array}$ & $\begin{array}{l}\text { Ginseng (Panaxsp., Aralia sp., } \\
\text { Eleuthrococuus sp.) }\end{array}$ \\
\hline Essential oils & $\begin{array}{l}\text { Perfumes, cosmetics, tumors, } \\
\text { immune/anti-inflammatory boosters } \\
\text { anti-allergens, antihistamines, sedatives }\end{array}$ & $\begin{array}{l}\text { Lemons (Citrus sp.), Lemon grass } \\
\text { (Andropogon citrata, A. flesuosa) }\end{array}$ \\
\hline
\end{tabular}

Table 3. Fifty Common Native Florida Plants and their Ethnobotanical Uses.

\begin{tabular}{|c|c|c|}
\hline $\begin{array}{l}\text { Acer rubrum L. Aceraceae (Maple family) } \\
\text { Red Maple - medium sized tree, with young branches appearing red, generally found southward through } \\
\text { south Florida, to east Texas and Oklahoma, northward up to east Canada. Mostly in lowland woods, coastal } \\
\text { plains, in and along swamps, floodplain forests, river and stream banks. } \\
\text { Although A. saccharum is the best source for producing maple syrup (Peterson, 1977), all maple trees } \\
\text { produce sugary sap. In the 1800s native American tribes introduced settlers to red maple. The wood of the } \\
\text { tree has been employed for making tools, such as cookware, arrowheads, and ox yokes. Medical accounts } \\
\text { of various acer species relate its use by Indians and settlers for liver and skin disorders, as well as in } \\
\text { ophthalmalic treatments. }\end{array}$ & $\begin{array}{r}\text { Transportation } \\
\text { Medicinal } \\
\text { Food } \\
\text { Housing } \\
\text { Textiles/Tools } \\
\text { Danger }\end{array}$ & $\begin{array}{l}- \\
X \\
X \\
- \\
- \\
-\end{array}$ \\
\hline $\begin{array}{l}\text { Annona glabra L. Annonaceae (Custard-Apple family) Plate } 2 . \\
\text { Pond-apple - common tree throughout the tropics and west Africa. This plant is no longer abundantly found } \\
\text { and is currently restricted to south Florida swamps and bogs. Fruit are yellow with pinkish orange inside. } \\
\text { CAUTION powder from seeds, used as fish poison, can cause irritation and blindness. Fruits can be eaten } \\
\text { raw, boiled, or made into jellies (Morton, 1974). Early Indians and settlers used fruit as a food. Few } \\
\text { references for various plant parts used in the making of lye. }\end{array}$ & $\begin{array}{r}\text { Transportation } \\
\text { Medicinal } \\
\text { Food } \\
\text { Housing } \\
\text { Textiles/Tools } \\
\text { Danger }\end{array}$ & $\begin{array}{l}- \\
- \\
X \\
- \\
- \\
X\end{array}$ \\
\hline $\begin{array}{l}\text { Apios americana Medic Leguminosae (Bean family) Plate } 3 . \\
\text { American Groundnut; Potato-bean - twining vine found throughout Florida and Texas, north to Nova } \\
\text { Scotia, New Brunswick, Minnesota, and South Dakota. Preferring rich fertile soil, it is found at the borders of } \\
\text { swamps, stream banks, shoreline thickets, meadows, wet clearings, and open woodlands. } \\
\text { Duke (2000) cites medical uses for groundnut, for cancer treatments. Commonly was and is used as a food } \\
\text { due to the nutty-like flavor and availability in all seasons. Throughout its North America range, the tiny tubers } \\
\text { have been eaten by indigenous peoples, explorers, and pioneering settlers. }\end{array}$ & $\begin{array}{r}\text { Transportation } \\
\text { Medicinal } \\
\text { Food } \\
\text { Housing } \\
\text { Textiles/Tools } \\
\text { Danger }\end{array}$ & $\begin{array}{l}- \\
X \\
X \\
- \\
-\end{array}$ \\
\hline
\end{tabular}


Table 3. Fifty Common Native Florida Plants and their Ethnobotanical Uses.

\begin{tabular}{|c|c|c|}
\hline $\begin{array}{l}\text { Asclepius tuberosa L. Asclepiadaceae (Milkweed family) } \\
\text { Butterflyweed, Pleurisy root - perennial herb growing from south New Hampshire through Florida, } \\
\text { westward to Texas, north to Minnesota. Usually in dry habitats, but also in moist pinelands. } \\
\text { Lacking milky sap, it is used as an ornamental to attract butterflies. Used medicinally by Indians and settlers } \\
\text { for bronchial conditions (pleurisy) also topically for bruises and sore muscles. Southeast tribal accounts } \\
\text { state the entire plant was boiled and eaten as a vegetable. A strong chord was made with Indian hemp } \\
\text { (Apocynum cannabinum). } \\
\text { CAUTION large quantities may be harmful (Foster and Duke, 2000). }\end{array}$ & $\begin{array}{r}\text { Transportation } \\
\text { Medicinal } \\
\text { Food } \\
\text { Housing } \\
\text { Textiles/Tools } \\
\text { Danger }\end{array}$ & $\begin{array}{l}- \\
X \\
X \\
- \\
X \\
X\end{array}$ \\
\hline $\begin{array}{l}\text { Callicarpa americana L. } \\
\text { Beautyberry, French Mulberry - shrub ranging from Maryland southward to Florida, west to Tennessee, } \\
\text { Arkansas, Texas, and Mexico, also throughout the Caribbean Islands. In many habitats, but usually shaded; } \\
\text { most common on fence lines, thickets, and well-drained woodlands. Fruit rarely white to violet in color. } \\
\text { Favored among southeastern Indian tribes as a ceremonial plant and as a tea used in sweat bath rituals. } \\
\text { Southern fold remedy; berries, roots, and leaves steeped in a tea to treat dropsy, skin disorders, stomach } \\
\text { disorders, and colic. }\end{array}$ & $\begin{array}{r}\text { Transportation } \\
\text { Medicinal } \\
\text { Food } \\
\text { Housing } \\
\text { Textiles/Tools } \\
\text { Danger }\end{array}$ & $\begin{array}{l}- \\
X \\
- \\
- \\
- \\
-\end{array}$ \\
\hline $\begin{array}{l}\text { Cephalanthus occidentalis L. } \\
\text { Rubiaceae (Madder/Coffee family) Plate } 5 . \\
\text { Buttonbush - scrubby shrub found from eastern Canada southward throughout Florida, west to California, } \\
\text { and in Mexico. Generally found in moist wetland habitats. Numerous, small, white "button-like" flowers. } \\
\text { A favorite among American Indian tribes, practically all parts have had medical applications. The inner bark } \\
\text { is said to have dental, ophthalmalic, and liver functions. The leaves are often made into a tea for } \\
\text { "woman's" medicine and for treatment of blood disorders and fevers. } \\
\text { WARNING contains glucosides cephalanthan and cephalin, grazing animals have been poisoned (Foster } \\
\text { and Duke, 2000). }\end{array}$ & $\begin{array}{r}\text { Transportation } \\
\text { Medicinal } \\
\text { Food } \\
\text { Housing } \\
\text { Textiles/Tools } \\
\text { Danger }\end{array}$ & $\begin{array}{l}- \\
x \\
- \\
- \\
- \\
x\end{array}$ \\
\hline $\begin{array}{l}\text { Chamaecrista fasciculata Fabaceae (Pea Family) } \\
\text { Partridge Pea- a herbaceous annual found in well-drained open areas throughout the southeastern United } \\
\text { States and in all but } 4 \text { north central Florida Counties. } \\
\text { Native American Indians used the roots of this plant as a medicine to keep people from tiring. The leaves } \\
\text { were used to make a tea to prevent fainting. Syrups (decoctions) with added honey were given to treat } \\
\text { nausea. Syrups were made by boiling parts of the plant in water and then straining the mixture and adding a } \\
\text { second ingredient to improve the flavor. }\end{array}$ & $\begin{array}{r}\text { Transportation } \\
\text { Medicinal } \\
\text { Food } \\
\text { Housing } \\
\text { Textiles/Tools } \\
\text { Danger }\end{array}$ & $\begin{array}{l}- \\
X \\
- \\
- \\
-\end{array}$ \\
\hline $\begin{array}{l}\text { Chysobalnus icaco L. Chrysobalanceae (Cocoa Plum family) } \\
\text { Cocoplum - shrub or small tree occurs throughout coastal regions of the American tropics and in south } \\
\text { Florida. Occurs in cypress hammocks, coastal dunes, and wetland areas. } \\
\text { Fruit used by Glades and Seminole Indians for food. Wood ashes used by Seminoles for love medicine. } \\
\text { Branches used to make arrows by Seminoles. Preserves currently made from fruit for export industry. }\end{array}$ & $\begin{array}{r}\text { Transportation } \\
\text { Medicinal } \\
\text { Food } \\
\text { Housing } \\
\text { Textiles/Tools } \\
\text { Danger } \\
\end{array}$ & $\begin{array}{l}- \\
X \\
X \\
- \\
X\end{array}$ \\
\hline $\begin{array}{l}\text { Cladium jamaicense Crantz. } \\
\text { Sawgrass - principal plant of the Everglades, common in marshes from Virginia to Texas, some in West } \\
\text { Indies. Tolerant of saline, alkaline or acidic, poorly drained to sandy soils. Leaves with saw-toothed margin. } \\
\text { Plant was used to make small baskets by some Indian tribes. Seminoles made medicine blowing tubes from } \\
\text { the stems (Moerman, 1998). The heart at the base of the stalk is edible, and may have been a survival food. }\end{array}$ & $\begin{array}{r}\text { Transportation } \\
\text { Medicinal } \\
\text { Food } \\
\text { Housing } \\
\text { Textiles/Tools } \\
\text { Danger }\end{array}$ & \\
\hline $\begin{array}{l}\text { Cucurbita moschata Poiret } \\
\text { Seminole Pumpkin; Winter Crookneck Squash - creeping vine common in south Florida. Grows in moist } \\
\text { or dry soils, in swamp hammocks, near historical Indian campsites. Fruits have many shapes, with orange or } \\
\text { yellow flesh. } \\
\text { This plant was a staple food for early Indian tribes especially the Seminoles. The fruits and flowers have } \\
\text { been, and still are, employed in soups, breadmaking, or eaten as a vegetable. The leaves are infrequently } \\
\text { used as a vegetable or meat stuffing. Now found around the world, it is especially regarded in Greece and } \\
\text { Italy. }\end{array}$ & $\begin{array}{r}\text { Transportation } \\
\text { Medicinal } \\
\text { Food } \\
\text { Housing } \\
\text { Textiles/Tools } \\
\text { Danger }\end{array}$ & $\begin{array}{l}- \\
- \\
x \\
- \\
- \\
-\end{array}$ \\
\hline
\end{tabular}


Table 3. Fifty Common Native Florida Plants and their Ethnobotanical Uses.

\begin{tabular}{|c|c|c|}
\hline $\begin{array}{l}\text { Drosera capillaris Poir. } \\
\text { Pink Sundew - common herb found in the tropical Americas, Virginia through Florida, westward to Texas. } \\
\text { Prefers wet sandy soils, common to bogs, savannas, and coniferous flatwoods. Carnivorous plant with a } \\
\text { basal rosette. } \\
\text { The leaves are well known to contain enzyme digesting proteins and plumbagin (an antibiotic). Many Native } \\
\text { American tribes used this plant topically for bacterial and other skin disorders such as ringworm and warts. }\end{array}$ & $\begin{array}{r}\text { Transportation } \\
\text { Medicinal } \\
\text { Food } \\
\text { Housing } \\
\text { Textiles/Tools } \\
\text { Danger }\end{array}$ & $\begin{array}{l}- \\
x \\
- \\
- \\
-\end{array}$ \\
\hline $\begin{array}{l}\text { Eryngium yuccifolium Michx. Umbelliferae (Carrot family) } \\
\text { Button Snake-Root, Rattlesnake Master - perennial herb found throughout Florida, westward to Texas, } \\
\text { Oklahoma, and Kansas, northward from Connecticut to Minnesota. Prefers sandy, well drained, slightly } \\
\text { acidic soils of pinewoods, bogs, swamps, prairies, and ditches. } \\
\text { American Indian tribes used this "pashe" in rituals, preparing warriors for battle, and purification at } \\
\text { funerals. In "woman's" medicine, root concoctions and tinctures were prepared for blood disorders, as a } \\
\text { diuretic, and in the treatment of snakebite. Common ingredient for fever treatment, both by Native tribes and } \\
\text { Florida settlers. } \\
\text { CAUTION resembles plants that are considered mildly to extremely toxic. Make sure of species before } \\
\text { touching it. }\end{array}$ & \begin{tabular}{r|} 
Transportation \\
Medicinal \\
Food \\
Housing \\
Textiles/Tools \\
Danger
\end{tabular} & $\begin{array}{l}- \\
x \\
- \\
- \\
-\end{array}$ \\
\hline $\begin{array}{l}\text { Eupatorium perfoliatum L. } \\
\text { Boneset, Thoroughwort - perennial herbaceous plant found throughout eastern U.S., westward to Kansas } \\
\text { and east Texas, with northern ranges into Nova Scotia, Quebec, and North Dakota. Common in low } \\
\text { wetlands, thickets, and along river and stream banks. } \\
\text { Native Indian tribes introduced Early American settlers to plant uses. Used extensively during the } 19 \text { th and } \\
20 \text { th centuries for flu treatment and associated muscle aches (breakbone fevers). Without further chemical } \\
\text { characterization and due to immune-stimulating properties, possibly alkaloids (harmful to the liver), it may } \\
\text { never be widely used. }\end{array}$ & $\begin{array}{r}\text { Transportation } \\
\text { Medicinal } \\
\text { Food } \\
\text { Housing } \\
\text { Textiles/Tools } \\
\text { Danger }\end{array}$ & $\begin{array}{l}- \\
X \\
- \\
- \\
- \\
-\end{array}$ \\
\hline $\begin{array}{l}\text { Ficus aurea Nutt. Moraceae (Mulberry family) } \\
\text { Strangler Fig - usually a tree, with aerial roots that can become epiphytic to other plants sometimes } \\
\text { "strangling" them. Scattered throughout the Cayman islands, Jamaica, Cuba, and Hispaniola, this plant is } \\
\text { abundant throughout south Florida, limited northern distribution in north central Florida. Found growing on } \\
\text { mostly wet to slow drained soils of drainage canals, swamps, tropical hammocks, mangrove edges, and } \\
\text { cypress domes. Fruits; spheres yellow (unripe), dark red (ripe). } \\
\text { Not the same figs you buy in a grocery store, but the fruits are edible (raw) and have been eaten by } \\
\text { indigenous peoples of Florida and settlers. The latex of this plant has been processed into chewing gum by } \\
\text { many of the southern Florida Indian tribes. It is also said that Native tribes made a poultice from the inner } \\
\text { bark for treating sores and cuts. Reports imply usage of the aerial roots for making lashings, arrows, } \\
\text { bowstrings, and fishing lines. }\end{array}$ & $\begin{array}{r}\text { Transportation } \\
\text { Medicinal } \\
\text { Food } \\
\text { Housing } \\
\text { Textiles/Tools } \\
\text { Danger }\end{array}$ & $\begin{array}{l}- \\
x \\
x \\
- \\
x \\
-\end{array}$ \\
\hline $\begin{array}{l}\text { Hamamelis virginiana L. Hamamelidaceae (Witch-hazel family) Plate } 7 . \\
\text { Witch-hazel - common shrub or small tree found throughout the eastern U.S. growing along stream banks, } \\
\text { bogs, and floodplain forests. } \\
\text { Present in many commercial remedies for the treatment of hemorrhoids, insect bites, and teething infants. } \\
\text { Astringent components are widely used, and the volatile oils are used to scent commercial products. Well } \\
\text { known by Native tribes of the U.S. for its medicinal properties, it is believed that they taught its uses to } \\
\text { settlers. By the early 19th century, this information was published in both the U.S. and Europe. Since the } \\
1920 \text { s, vast quantities of distilled dried leaf extract (mainly from Virginia, North Carolina, and Tennessee) } \\
\text { have been sold commercially worldwide. }\end{array}$ & $\begin{array}{r}\text { Transportation } \\
\text { Medicinal } \\
\text { Food } \\
\text { Housing } \\
\text { Textiles/Tools } \\
\text { Danger }\end{array}$ & $\begin{array}{l}- \\
x \\
- \\
- \\
- \\
-\end{array}$ \\
\hline $\begin{array}{l}\text { Hydrocotyle umbellata L. Umbelliferae (Carrot family) } \\
\text { Marsh pennywort - aquatic plant; sometimes in floating mats, present in most Florida counties, westward to } \\
\text { Texas, California, Oregon, and Oklahoma, northward to Nova Scotia and Minnesota. Used by many U.S. } \\
\text { native American tribes for respiratory ailments. The close relative Indian pennywort (Centella asiatica L.) has } \\
\text { long been cited in literature as Hydrocotyle. The stems and leaves of Indian pennywort are utilized to } \\
\text { produce the drug gotu kola (Tyler, Brady, and Robbers, 1988) pantropically used as a blood purifier, } \\
\text { diueretic, longevity promotor, and in treating leprosy. }\end{array}$ & $\begin{array}{r}\text { Transportation } \\
\text { Medicinal } \\
\text { Food } \\
\text { Housing } \\
\text { Textiles/Tools } \\
\text { Danger }\end{array}$ & $\begin{array}{l}- \\
X \\
- \\
- \\
- \\
-\end{array}$ \\
\hline
\end{tabular}


Table 3. Fifty Common Native Florida Plants and their Ethnobotanical Uses.

\begin{tabular}{|c|c|c|}
\hline $\begin{array}{l}\text { Alex vomitoria Ait. } \\
\text { Yaupon - evergreen shrub or tree found on the coastal plains from north central peninsular Florida to } \\
\text { Virginia, west to Texas, southeast Oklahoma, and Arkansas. Many (60) species worldwide. Prefer } \\
\text { well-drained soils of woodlands, pinelands, stream banks, and flood plains; often an ornamental. Fruit bright } \\
\text { red (rare yellow) drupe. } \\
\text { One of the primary ingredients in the famed "Black Drink" of southeast U.S. Indian tribes, its history of } \\
\text { uses dates back to the early 1500s. Indigenous cultures used the plant primarily in ceremonial settings, as } \\
\text { the leaves contain large quantities of caffeine and they desired the stimulating effect. Seminoles used the } \\
\text { bark as a medicine for "old people's" sickness or nightmares (Moerman, 1998). Yaupon branches were used } \\
\text { in making arrows. Popularity among southeast U.S. pioneers grew when it was sold as a substitute for teas } \\
\text { that were difficult to import from India during the American Revolution and Civil War. Both } I \text {. vomitoria (high in } \\
\text { caffeine) and } I \text {. cassine (little to no caffeine) are known as cassina and cassine, causing problems for early } \\
\text { pharmaceutical research. }\end{array}$ & $\begin{array}{r}\text { Transportation } \\
\text { Medicinal } \\
\text { Food } \\
\text { Housing } \\
\text { Textiles/Tools } \\
\text { Danger }\end{array}$ & $\begin{array}{l}- \\
X \\
- \\
- \\
X \\
-\end{array}$ \\
\hline $\begin{array}{l}\text { Liquidambar styraciflua L. Hamamelidaceae (Witch-hazel family) Plate } 8 . \\
\text { Sweet Gum, Red Gum - tree found throughout Florida and most of the eastern U.S. Inhabits mesic } \\
\text { woodlands, wet swamps, and will grow in standing water. Aromatic star-shaped leaves with serrated edges. } \\
\text { Storax is a balsam obtained from the plant and sold commercially in many pharmaceutical products used as } \\
\text { stimulants, antiseptics, and expectorants. The use of the Asia minor specie L. orientalis dates back to 12th } \\
\text { century. The American variety was documented as early as the 16th century, with indigenous citations } \\
\text { throughout the 19th century. During the Civil War, Confederate doctors used the leaves as an astringent and } \\
\text { to treat diarrhea and dysentery. European settlers did not use the plant until the late 19th and 20th } \\
\text { centuries. Today, most pharmaceutical storax comes from Turkey and Honduras, with American storax } \\
\text { being used in cigarettes, candy, soda pop, and chewing gum as a flavoring agent. }\end{array}$ & $\begin{array}{r}\text { Transportation } \\
\text { Medicinal } \\
\text { Food } \\
\text { Housing } \\
\text { Textiles/Tools } \\
\text { Danger }\end{array}$ & $\begin{array}{l}- \\
X \\
X \\
- \\
- \\
-\end{array}$ \\
\hline $\begin{array}{l}\text { Mikania batatifolia D.C. } \\
\text { Climbing Hempvine; Hempweed - herbaceous vine commonly densely matted over herbs, small trees, } \\
\text { and shrubs. Native to the tropical Americas. In North America, the range of distribution extends from } \\
\text { southern Ontario to south Florida and east to Texas. Found along swamp edges, bogs, wet prairies, ditches, } \\
\text { and commonly in water. } \\
\text { The plant was used as a dermatological aid by many of the southeastern U.S. Indian tribes (Moerman, } \\
\text { 1998). }\end{array}$ & $\begin{array}{r}\text { Transportation } \\
\text { Medicinal } \\
\text { Food } \\
\text { Housing } \\
\text { Textiles/Tools } \\
\text { Danger }\end{array}$ & $\begin{array}{l}- \\
X \\
- \\
- \\
- \\
-\end{array}$ \\
\hline $\begin{array}{l}\text { Myrica cerifera L. Myracaceae (Bayberry family) } \\
\text { Wax-myrtle, Southern Bayberry - shrub or small tree distributed from New Jersey, throughout Florida, west } \\
\text { to Texas, Oklahoma, Arkansas; south to Bermuda and Central America. Found in most habitats including } \\
\text { fresh and brackish water banks, savannas, swamps, pastures, and woodlands. } \\
\text { Waxy berry coating is removed by boiling. As four pounds yields one pound of wax, other plant relatives are } \\
\text { more commonly used for bayberry candles. Seminoles (Moerman, 1998) fermented leaves into a tonic for } \\
\text { headaches, fevers, and stomachaches. A mixture of wood ashes was placed on tongues of newly married } \\
\text { couples to strengthen their marriage. Introduced to European settlers in 1700s, the wax was an ingredient in } \\
\text { surgeon's soap, shaving lather, and sealing wax. Planted around homes to keep fleas out and placed in } \\
\text { closets to keep cockroaches away. }\end{array}$ & $\begin{array}{r}\text { Transportation } \\
\text { Medicinal } \\
\text { Food } \\
\text { Housing } \\
\text { Textiles/Tools } \\
\text { Danger }\end{array}$ & $\begin{array}{l}- \\
X \\
- \\
- \\
- \\
-\end{array}$ \\
\hline $\begin{array}{l}\text { Nymphea odorata Ait. Nymphaeaceae (Water-Lily family) Plate } 10 . \\
\text { White Water-Lily, Pond Lily - aquatic plant found from Quebec southward through Florida, Oklahoma, } \\
\text { Texas, and Arizona. Common in ponds, lakes, marshes, sluggish streams, ditches, canals, and swamps. } \\
\text { Leaves heart shaped in outline, usually green above and purplish below. Flowers fragrant, white (sometimes } \\
\text { pink), and floating. } \\
\text { The young leaves, seeds, and tubers ( } N \text {. tuberosa), are edible delicacies. Both indigenous tribes and } \\
\text { European settlers (taught by the Native tribes) found food and medicinal value for this plant throughout its } \\
\text { range. North Carolina listed the plant as a remedy against bronchial problems, sore throats, and } \\
\text { dermatological ailments. The chemistry is yet undefined; however, alkaloids, and many tannins } \\
\text { (dermatological interests) are present. }\end{array}$ & $\begin{array}{r}\text { Transportation } \\
\text { Medicinal } \\
\text { Food } \\
\text { Housing } \\
\text { Textiles/Tools } \\
\text { Danger }\end{array}$ & $\begin{array}{l}- \\
X- \\
X \\
- \\
- \\
-\end{array}$ \\
\hline
\end{tabular}


Table 3. Fifty Common Native Florida Plants and their Ethnobotanical Uses.

\begin{tabular}{|c|c|c|}
\hline $\begin{array}{l}\text { Plate } 11 . \\
\text { Varieties: (Eastern (O. humifusa Raf.), Southern (O. austrina Small.), Erect (O. dillenii Haw.) Cactaceae } \\
\text { (Cactus) } \\
\text { Prickly-Pear Cactus, Indian fig -all above found in Florida, the Eastern species is found throughout } \\
\text { eastern U.S., Southern; southeast coastal plain, with the Erect variety only found in Florida and the tropics. } \\
\text { Cacti prefer well-drained, sandy, or rocky soils of sand dunes, pastures, woodlands, coastal hammocks, and } \\
\text { mangrove swamps. Leaves in pads, spined, flowers red, salmon or yellow, fruits red or purple, pear shaped. } \\
\text { Rich in beta-carotene, potassium, phosphorous, calcium, and vitamin C, all parts are edible (after } \\
\text { preparation) or used as thickening agents. Used by native peoples and settlers throughout plant range. } \\
\text { Folklore (Indian and pioneer) medical applications were for treatments of lung, kidney, and urinary disorders. } \\
\text { Modern investigations are lacking. } \\
\text { CAUTION has many tiny spines with barbs. Gloves are recommended when preparing the plant and fruit. }\end{array}$ & $\begin{array}{r}\text { Transportation } \\
\text { Medicinal } \\
\text { Food } \\
\text { Housing } \\
\text { Textiles/Tools } \\
\text { Danger }\end{array}$ & $\begin{array}{l}- \\
\mathrm{X} \\
\mathrm{X} \\
- \\
- \\
-\end{array}$ \\
\hline $\begin{array}{l}\text { Passiflora incarnata L. Passifloraceae (Passion flower or Maypop family)Plate } 12 . \\
\text { Purple Passion flower, Maypop - climbing vine with a range from Florida west to Texas, north to } \\
\text { Pennsylvania, east to Missouri. Found in shaded thickets, fence lines, and wooded areas with well drained } \\
\text { sandy, fertile soils. } \\
\text { The name maypop thought to originate from the popping sound made when the fruits (yellow or orange } \\
\text { berries) are crushed. A favorite game of pioneer children of the Southern United States was to jump on the } \\
\text { fruits. Passion flowers have been and still are used in many cultures as food and medicine. The fruits, with } \\
\text { skin, can be eaten cooked or raw after removing seeds. The pulp can be prepared into jams, syrups, and } \\
\text { beverages. Leaves are used to make drinking or tonic teas. Medicinally, most species of this genus have } \\
\text { use as a sedative, or calming agent. An estimated } 50 \text { European sedation drugs and U.S. natural products } \\
\text { contain passionflower extracts. } \\
\text { CAUTION possible presence of cyanogenic glycosides in Passiflora. }\end{array}$ & $\begin{array}{r}\text { Transportation } \\
\text { Medicinal } \\
\text { Food } \\
\text { Housing } \\
\text { Textiles/Tools } \\
\text { Danger }\end{array}$ & $\begin{array}{l}- \\
x \\
x \\
- \\
- \\
x\end{array}$ \\
\hline $\begin{array}{l}\text { Persea borbonia L. Spreng. } \\
\text { Red-bay, Swamp-bay - shrub or small tree found throughout the coastal plain, from Virginia to south Florida, } \\
\text { west to Texas. Common in mesic to xeric habitats; woodlands, hammocks, pinewoods, swamps, and } \\
\text { marsh/stream edges. Flowers whitish. Fruit a dark drupe. Preferring wetter places is the species } P \text {. } \\
\text { palustris (Raf.) Sarg. } \\
\text { Culinary bay leaves are used as a flavoring agent. Bay leaves in Florida are not the same. However, they } \\
\text { were and still are employed in the same manner by Native Americans and settlers alike. Used medically as } \\
\text { an analgesic, in rituals such as funerals, and also as a love potion by some southeast American Indian tribes. }\end{array}$ & $\begin{array}{r}\text { Transportation } \\
\text { Medicinal } \\
\text { Food } \\
\text { Housing } \\
\text { Textiles/Tools } \\
\text { Danger }\end{array}$ & $\begin{array}{l}- \\
x \\
x\end{array}$ \\
\hline $\begin{array}{l}\text { Phlebodium aureum (L.) J. Smith Plate } 14 . \\
\text { Golden Polypody, Goldenfoot Fern - epiphytic fern widely distributed throughout the New World Tropics } \\
\text { is frequent in Florida, Alabama, Georgia, Hawaii, Puerto Rico, West Indies, Virgin islands, Mexico, Central } \\
\text { and South America. Commonly in wetter places, hammocks, mixed woods, and swamps; occuring on logs, } \\
\text { trees and Sabal palm (Sabal palmetto). Creeping, thick stems are brown to golden, and covered with scales } \\
\text { resembling feet. } \\
\text { Reported in indigenous and pioneer literature are general treatments for ill babies. A complex root mixture } \\
\text { containing Resurrection fern (Polypodium incanum) and Shoestring fern (Vittaria lineata) was made by } \\
\text { Florida Seminole and Mikasuki to treat chronic conditions (Sturtevant 1954). All of the above ferns were } \\
\text { used in baths to treat insanity by many native tribes. }\end{array}$ & $\begin{array}{r}\text { Transportation } \\
\text { Medicinal } \\
\text { Food } \\
\text { Housing } \\
\text { Textiles/Tools } \\
\text { Danger }\end{array}$ & $\bar{x}$ \\
\hline $\begin{array}{l}\text { Phorandendron serotinum (Raf.) M.C. Johnston Loranthaceae (Mistletoe family) } \\
\text { American Mistletoe, Oak Mistletoe - parasitic evergreen shrub called the "thief" from the Greek } \\
\text { "phor" and "dendron," tree. Found throughout Florida, east to Texas, north to southeast Kansas and New } \\
\text { Jersey. Usually distributed by birds eating the seeds, this plant can be found on the branches of many oaks } \\
\text { (Quercus sp.) but never Live Oak. Flowers small clusters in the joints, fruit a 1-seeded berrylike, white or } \\
\text { yellowish drupe. } \\
\text { Mistletoe (kissing branches, wreaths) is used in the Christmas holiday season, stemming from Scandinavian } \\
\text { and Druid legends and myths. There are many citations for medical and mythical use in folklore worldwide. } \\
\text { American varieties have chemical properties that stimulate smooth muscles. The leaves have long been } \\
\text { used for teas. Southeast U.S. Indian tribes made topical preparations. } \\
\text { EXTREME CAUTION all plant parts considered POISONOUS, some species may be able to extract toxic } \\
\text { compounds from their host plants. Toxic protein phoratoxin found mostly in the stems and leaves. }\end{array}$ & $\begin{array}{r}\text { Transportation } \\
\text { Medicinal } \\
\text { Food } \\
\text { Housing } \\
\text { Textiles/Tools } \\
\text { Danger }\end{array}$ & \\
\hline
\end{tabular}


Table 3. Fifty Common Native Florida Plants and their Ethnobotanical Uses.

\begin{tabular}{|c|c|c|}
\hline $\begin{array}{l}\text { Phytolacca americana L. } \\
\text { Pokeweed, Pokeberry - perennial herb, distribution throughout Florida, Texas and Arizona, north to Maine, } \\
\text { and Minnesota. Prefers well drained to wet habitats such as moist woodlands and fields (sometimes } \\
\text { flooded), and riverbanks. Purplish stems, white to pinkish flowers on stalks, fruit is a dark purple - black berry. } \\
\text { Southern poke salad is a local delicacy that contains many vitamins. All parts of the plant are considered } \\
\text { poisonous, but if processed correctly (several water changes) the young leaves are tender and eaten as a } \\
\text { vegetable, or put in salads. Festivals and parades honor the plant in southern U.S. Canned commercial } \\
\text { goods are exported to Africa and Europe. } \\
\text { Highly regarded as a medicine first by Native American tribes, later by settlers. Usage includes; emetic, } \\
\text { cathartic, dyspepsia treatment, chronic rheumatism, and ringworm. Because pokeweed is highly toxic, it was } \\
\text { used by the best-trained medicine people, and physicians of the time, not by the casual practitioner. } \\
\text { EXTREME CAUTION every part of the plant is HIGHLY TOXIC. Many people have become fatally ill after } \\
\text { consumption. Symptoms are extreme stomach upset and depressed breathing. Gloves should be worn when } \\
\text { handling. }\end{array}$ & $\begin{array}{r}\text { Transportation } \\
\text { Medicinal } \\
\text { Food } \\
\text { Housing } \\
\text { Textiles/Tools } \\
\text { Danger }\end{array}$ & $\begin{array}{l}- \\
X \\
X \\
- \\
- \\
X\end{array}$ \\
\hline $\begin{array}{l}\text { Pinus elliottii (var. elliottii E., var. densa L. \& D.) Pinaceae (Pine family) } 15 . \\
\text { Slash Pine - medium to large unbranched tree endemic to Florida, common in southern Florida. Also found } \\
\text { from southeast South Carolina, west through Louisiana, and Mississippi. Usually in low, wet flatwoods of } \\
\text { poorly drained, acidic soils, and coastal sands. National Champion of } 1977 \text { (var. densa) reached } 55 \text { feet tall, } \\
11.5 \text { feet circumference, with a } 63 \text { foot spread (Sarasota, Fla.). } \\
\text { The "exceedingly" (Morton, 1974) hard heartwood has always been a favorite in southern folk and } \\
\text { indigenous architecture, resulting in large-scale logging with harvesting continuing into the } 21 \text { st century. } \\
\text { Commercial processes include use in the paper industry and chemical industry (turpentine and gum resins). } \\
\text { Resins are obtained by slashing the pine bark like a "cat face" and harvesting the compound. The United } \\
\text { States is the world's largest producer of turpentine, with much of it coming from Florida. There are also } \\
\text { medical applications as a counter-irritant applied topically. Limited references imply the eating of inner bark } \\
\text { for food during famine times. }\end{array}$ & $\begin{array}{r}\text { Transportation } \\
\text { Medicinal } \\
\text { Food } \\
\text { Housing } \\
\text { Textiles/Tools } \\
\text { Danger }\end{array}$ & $\begin{array}{l}- \\
X \\
X \\
X \\
-\end{array}$ \\
\hline $\begin{array}{l}\text { Pontideria cordata L. Pontideriaceae (Pickerelweed family) Plate } 16 . \\
\text { Pickerelweed - creeping, rhizatomous, aquatic herb found throughout Florida and east to Texas and north } \\
\text { to Ontario and Minnesota. Often found in swamps, marshes, ditches, streams, and lakes. } \\
\text { The seeds and young, unfurled leaves can be eaten cooked or raw. The seeds are added to homemade } \\
\text { granola mixes. Fishermen would fish by the plants, believing pickerel fish might be there. Cultivated as an } \\
\text { ornamental water garden or aquarium plant. } \\
\text { CAUTION. Not poisonous, but known to absorb water contaminants. }\end{array}$ & $\begin{array}{r}\text { Transportation } \\
\text { Medicinal } \\
\text { Food } \\
\text { Housing } \\
\text { Textiles/Tools } \\
\text { Danger }\end{array}$ & $\begin{array}{l}- \\
- \\
X \\
- \\
- \\
-\end{array}$ \\
\hline $\begin{array}{l}\text { Quercus virginiana Mill Pagaceae (Oak and Beech family). } \\
\text { Live Oak - medium sized tree, native to the southeastern U.S. Sand Live Oak (Q. geminata Small.) is } \\
\text { limited in range to south central Florida, southeast Virginia, and west to Mississippi. Found in well drained to } \\
\text { seasonally wet soils of edges of salt marshes, pastures, mixed woodlands, hammocks, and roadsides. } \\
\text { Nutgalls (galls) found on young twigs. Blade appearance may vary on branches, within populations, and } \\
\text { between seasons. Summer leaves are often toothed and lobed, whereas winter leaves tend to be blunt. Fruit } \\
\text { an acorn. } \\
\text { Live oaks are of the "white" oak group having acorns less bitter than "red" oaks. Native Americans, } \\
\text { settlers and explorers alike harvested the acorns for food, with some southeast U.S. tribes using them in } \\
\text { animal feed. The wood (still prized) is often utilized as fuel, as well as in tool making. Uses include: building } \\
\text { (lumbers, timbers, etc.), component of mortar and caulks, sources of lye, and for tanning hides. There is a } \\
\text { mythical belief that "little people" live in the galls and should never be disturbed. The use of galls (Q. } \\
\text { infectoria) dates back to ancient Greeks ( } 450 \text { B.C.). Galls are formed when an insect (Cynips tinctoria) } \\
\text { deposits eggs in young wood. Galls are the chief source of tannic acid, used in tanning and dyeing, formerly } \\
\text { in ink manufacturing, and medicinally as an astringent. }\end{array}$ & $\begin{array}{r}\text { Transportation } \\
\text { Medicinal } \\
\text { Food } \\
\text { Housing } \\
\text { Textiles/Tools } \\
\text { Danger }\end{array}$ & $\begin{array}{l}- \\
X \\
X \\
X \\
X \\
-\end{array}$ \\
\hline
\end{tabular}


Table 3. Fifty Common Native Florida Plants and their Ethnobotanical Uses.

\begin{tabular}{|c|c|c|}
\hline $\begin{array}{l}\text { Rhus copallina L. Anacardiaceae (Sumac family) Plate } 18 . \\
\text { Winged Sumac, Shining Sumac - bushy shrub or small tree ranging southward through Florida and east to } \\
\text { Texas, extending northward through Missouri, Michigan, and New Hampshire. Common in old fields, along } \\
\text { wood edges, power lines, highways, railways, and hedgerows. Stems, in between leaf blades flat, and } \\
\text { forming wings. Flowers in panicles, whitish, and some with reddish tips. Fruit a dull, red drupe. } \\
\text { A distant relative to poison ivy; many "wild edible" manuals still include a recipe for a lemonade type drink } \\
\text { (bitter taste and vitamin C) which can be made from the berries. The leaves and berries are also well known } \\
\text { for their high tannin content. Prized as dyeing plant in American Indian herbology, and for its medicinal uses; } \\
\text { increasing milk flow dysentery, and bed-wetting. The Merck Medical Index (1968) lists it as an effective } \\
\text { poison antidote. } \\
\text { Caution contains exudates. Many people are sensitive to Anacardiaceae plants and develop mild to serious } \\
\text { skin rash. }\end{array}$ & $\begin{array}{r}\text { Transportation } \\
\text { Medicinal } \\
\text { Food } \\
\text { Housing } \\
\text { Textiles/Tools } \\
\text { Danger }\end{array}$ & $\begin{array}{l}- \\
x \\
- \\
- \\
x\end{array}$ \\
\hline $\begin{array}{l}\text { Rudbeckia hirta L. Compositae (Sunflower family) } \\
\text { Black-eyed Susan, Coneflower - herbaceous plant, found throughout the central and eastern United } \\
\text { States where the soil is moist, common along roadsides and waste areas. Flowers with yellow rays around a } \\
\text { dark brown center, daisy-like, this species is generally considered the true Black-eyed Susan. } \\
\text { Present day herbal guides suggest uses for flowers, roots and stems, in a variety of treatments. Use in } \\
\text { folklore and native American Indian herbology, as a headache remedy, did not lead to any scientific interest. } \\
\text { American Indians were also known to use the root in teas for colds and worms, externally as a wash for } \\
\text { snakebites, swelling, and sores, and root juice for earaches (Foster and Duke, 2000). } \\
\text { CAUTION many people get skin irritation when in contact with this and related species. }\end{array}$ & $\begin{array}{r}\text { Transportation } \\
\text { Medicinal } \\
\text { Food } \\
\text { Housing } \\
\text { Textiles/Tools } \\
\text { Danger }\end{array}$ & $\begin{array}{l}- \\
\mathrm{X} \\
- \\
- \\
- \\
-\end{array}$ \\
\hline $\begin{array}{l}\text { Rumex verticillatus } \mathrm{L} \text {. Polygonaceae (Smartweed family) } \\
\text { Swamp Dock, Sorrel - native herbaceous plant which prefers growing in wetland areas throughout most of } \\
\text { Florida. Rumexes in general have their origins from either Europe, or South America. Many of the European } \\
\text { varieties that possess medicinal applications occur as non-natives in Florida. Rumex verticillatus leaves } \\
\text { were used in a bath to prevent smallpox. }\end{array}$ & $\begin{array}{r}\text { Transportation } \\
\text { Medicinal } \\
\text { Food } \\
\text { Housing } \\
\text { Textiles/Tools } \\
\text { Danger }\end{array}$ & $\begin{array}{l}- \\
\mathrm{X} \\
- \\
- \\
- \\
-\end{array}$ \\
\hline $\begin{array}{l}\text { Sabal palmetto Rein Palmae (Palm family) } \\
\text { Sabal Palm, Cabbage Palm - Florida state tree, medium sized with solitary trunk. Widespread in southeast } \\
\text { United States from Florida to North Carolina and throughout Bahamas and west Cuba. Often found at or near } \\
\text { sea level on sandy soils common to inundated savannas, riverbanks, tree islands, dunes and flats. Fruits } \\
\text { pear shaped and black. } \\
\text { Swamp cabbage festivals are still popular events in Florida. It is undocumented whether native Americans } \\
\text { used the plant as a food source, however, early Floridians cut out the main bud and ate it cooked or raw. } \\
\text { This process kills the tree, so harvesting should be done only in dense stands. According to Moerman } \\
\text { (1998), Seminole uses include: berries for grass sickness, leaves used for thatch houses and mats, fiber, } \\
\text { arrows, food paddles, drying frames, staffs, and stickball. }\end{array}$ & $\begin{array}{r}\text { Transportation } \\
\text { Medicinal } \\
\text { Food } \\
\text { Housing } \\
\text { Textiles/Tools } \\
\text { Danger }\end{array}$ & $\begin{array}{l}- \\
\mathrm{X} \\
\mathrm{X} \\
- \\
\mathrm{X} \\
-\end{array}$ \\
\hline $\begin{array}{l}\text { Salix caroliniana Michx. } \\
\text { Coastal Plain Willow -generally a shrub, sometimes a tree, most common from Florida up through southern } \\
\text { Kansas, with some found in Cuba. Willows are found practically worldwide. Found in low, wet places, } \\
\text { swamps, and sandy soils around rivers. } \\
\text { Salicin (used in producing aspirin) is obtained from many willow barks, and has antirheumetic (pain } \\
\text { associated with joint swelling, arthritis) properties, which lead to the widespread usage in folklore. Medicinal } \\
\text { uses include, as an analgesic and emetic; to the mythical belief that root concoctions would increase hunting } \\
\text { success. }\end{array}$ & $\begin{array}{r}\text { Transportation } \\
\text { Medicinal } \\
\text { Food } \\
\text { Housing } \\
\text { Textiles/Tools } \\
\text { Danger }\end{array}$ & $\begin{array}{l}- \\
x \\
- \\
- \\
-\end{array}$ \\
\hline
\end{tabular}


Table 3. Fifty Common Native Florida Plants and their Ethnobotanical Uses.

\begin{tabular}{|c|c|c|}
\hline $\begin{array}{l}\text { Sambucus canadensis L. } \\
\text { Caprifoliceae (Honeysuckle family) } \\
\text { Elder-berry; Elderberry - shrub found from Florida to Texas and Mexico, with northern ranges of Nova } \\
\text { Scotia, and Quebec. Found in moist disturbed clearings, swamps, wet-woodlands, riverbanks, and ditches. } \\
\text { Soft-stemmed with white pith, " it produces a rank odor when crushed or bruised"(Godfrey and Wooten, } \\
\text { 1981). } \\
\text { Sambucus is derived from the Greek word "sambuke", a musical instrument believed to heal the spirit. } \\
\text { References to uses include food, liqueur, medicine, toys, musical instruments, and textile dyes. Sometimes } \\
\text { referred to as starvation food, it was used by southeastern U.S. Indian tribes (and likely settlers). The } \\
\text { berries are edible and commonly made into liqueurs, jams, pies, and syrups. Flowers can be dipped in flour, } \\
\text { deep-fried or eaten raw. Medical applications include ritual tools, emetic, and antiseptic used to treat wounds } \\
\text { and bee stings. Fresh berries, flowers and bark can be used for dyes. } \\
\text { CAUTION children became sick from playing with elderberry whistles and blowguns, plant contains } \\
\text { cyanogenic glucosides. }\end{array}$ & $\begin{array}{r}\text { Transportation } \\
\text { Medicinal } \\
\text { Food } \\
\text { Housing } \\
\text { Textiles/Tools } \\
\text { Danger }\end{array}$ & $\begin{array}{l}- \\
x \\
x \\
- \\
x \\
x\end{array}$ \\
\hline $\begin{array}{l}\text { Sassafras albidium (Nutt.) Nees. } \\
\text { Sassafras - small shrub to large tree generally a tree, found throughout Florida, eastward to Texas, } \\
\text { northward to southwest Maine, east Kansas and lowa. Prefers well-drained soils, which are usually found } \\
\text { along fencerows, hedges, fields, and woodlands. Often forms shrub thickets, all parts aromatic. The flowers } \\
\text { are yellow; fruits are dark blue drupes. } \\
\text { Native American Indians called it "green stick" tree because of its bright-green branches. According to } \\
\text { Moerman (1998), the bark of the root was used in medicine by the Seminoles for cow sickness (chest and } \\
\text { digestive pain), and the plant was made into a drink for wolf ghost sickness (digestive troubles), and as a } \\
\text { cold and cough mouthwash. Famous since pioneer days for making sassafras tea, made by boiling the bark } \\
\text { of the roots. Oil of sassafras is distilled from the roots and bark, and was/is used to perfume soaps and } \\
\text { lotions. Extracts of sassafras bark are used as flavoring agents in various beverages. } \\
\text { WARNING laboratory rats fed with sassafras developed tumors. }\end{array}$ & $\begin{array}{r}\text { Transportation } \\
\text { Medicinal } \\
\text { Food } \\
\text { Housing } \\
\text { Textiles/Tools } \\
\text { Danger }\end{array}$ & $\begin{array}{l}- \\
X \\
X \\
- \\
- \\
x\end{array}$ \\
\hline $\begin{array}{l}\text { Serenoa repens (Bartr.) Small Palmae (Palm family) } \\
\text { Saw palmetto - generally a shrub, sometimes a tree endemic to southeastern United States, very common } \\
\text { in Florida, Georgia, and less common in the Carolinas, Alabama, and Virginia. Found in sandy soils, } \\
\text { pinewoods, and sand dunes. Stems are usually subterranean, but sometimes are upright forming dense } \\
\text { colonies. Fruit dark blue to black in color. } \\
\text { The fruits have a long folk history as an aphrodisiac and have been used for centuries in treating conditions } \\
\text { of the prostate. Native American Indians used the saw palmetto fruits as a subsistence food in the fall. Base } \\
\text { of new leaf stalks were also cooked or eaten raw. The Seminoles used the plant for fiber; baskets, brooms, } \\
\text { fans, and ropes. Further uses included fish drags, fire/dance fans, and dolls. Modern day development of a } \\
\text { purified extract from the berries greatly improves symptoms of enlarged prostate. Florida is the biggest } \\
\text { source and producer of saw palmetto products. With about } 2,000 \text { tons harvested from South Florida and } \\
\text { exported to Europe each year, the fruit crop estimate is } \$ 50 \text { million a year in the state. }\end{array}$ & $\begin{array}{r}\text { Transportation } \\
\text { Medicinal } \\
\text { Food } \\
\text { Housing } \\
\text { Textiles/Tools } \\
\text { Danger }\end{array}$ & $\begin{array}{l}- \\
x \\
X \\
- \\
X \\
-\end{array}$ \\
\hline $\begin{array}{l}\text { Smilax laurifolia L. } \\
\text { Bamboo-vine, Laurel Greenbriar - evergreen shrub or vine ranges include Central New Jersey to south } \\
\text { Florida, westward to east Texas, Arkansas and west Tennessee; also in Bahama islands, and Cuba. Prefers } \\
\text { areas of prolonged inundation such as bogs, swamps, stream banks, cypress mounds, bays, and marshes. } \\
\text { Where there is no other vegetation, it may form thick, dense tangles. Thick, reddish in color, tuberous } \\
\text { rhizomes. Older stems, with irregular prickles, on lower part of stem. Berries, shiny black at maturity (second } \\
\text { season). } \\
\text { This species has been cited extensively as a dye plant, food, and medicine. Personal communication with } \\
\text { Dr. William Sturtevant suggests that Smilaxes were very important resources throughout the Caribbean, their } \\
\text { technologies and uses were brought to Florida with migration and slave trade. Wild asparagus is the term for } \\
\text { the young shoots that are a favorite in salads (or sautéed). In many species, a thickening agent (like gelatin) } \\
\text { can be processed from the rootstock, often used in jellies. William Bartram (Bartram and Bartram, 1957) cites } \\
\text { a number of Smilax sp. used to make bread or fritters in Florida. The flavoring agent sarsaparilla is obtained } \\
\text { from more southern species (Mexico, Hondorus, and Ecuador). Modern uses of Smilaxes include synthetic } \\
\text { cortisone and steroid production. }\end{array}$ & $\begin{array}{r}\text { Transportation } \\
\text { Medicinal } \\
\text { Food } \\
\text { Housing } \\
\text { Textiles/Tools } \\
\text { Danger }\end{array}$ & $\begin{array}{l}- \\
X \\
X \\
- \\
-\end{array}$ \\
\hline
\end{tabular}


Table 3. Fifty Common Native Florida Plants and their Ethnobotanical Uses.

\begin{tabular}{|c|c|c|}
\hline $\begin{array}{l}\text { Solanaceae (Nightshade family) } \\
\text { Common oleraceus L. } \\
\text { Common in disturbed soils associated with fields, pastures, roadsides, meadows, also coastal and } \\
\text { ornamental. } \\
\text { Romans ( } 23-29 \text { A.D.) used sowthistle leaves and stalks as a salad herb and vegetable, recommending it as } \\
\text { nourishing, curative, and sustaining. The species name of oleraceus means "an edible vegetable". The } \\
\text { leaves are high in minerals and vitamin C. A } 13 \text { th-century herbalist recommended a diet of sowthistles "to } \\
\text { prolong the virility of gentlemen." In the } 16 \text { th century, people who couldnt afford goose down stuffed their } \\
\text { mattresses and pillows with sowthistle down. Early } 17 \text { th century herbalists used its medical powers to } \\
\text { combat bad breath, deafness, wheezing, and as a facial cosmetic, to clear the skin and give it luster. } \\
\text { Sowthistle stems are filled with milky juice, which in early times suggested it could stimulate milk production, } \\
\text { hence it was given to nursing mothers (human and animal). Still valued today, especially in England, as a } \\
\text { veterinary herb, and for the treatment of fevers, high blood pressure, and heart disorders. Sowthistle is also } \\
\text { a favorite livestock food but has invaded crops in } 56 \text { countries and is considered one of the world's worst } \\
\text { weeds. } \\
\text { CAUTION not poisonous, but does have a tendency to absorb nitrogen containing contaminants from the } \\
\text { soil. }\end{array}$ & $\begin{array}{r}\text { Transportation } \\
\text { Medicinal } \\
\text { Food } \\
\text { Housing } \\
\text { Textiles/Tools } \\
\text { Danger }\end{array}$ & $\begin{array}{l}- \\
x \\
x \\
- \\
x \\
-\end{array}$ \\
\hline $\begin{array}{l}\text { Stachys floridana Shuttlw. Ex Benth. in DC. Labiate (Mint family) } \\
\text { Florida Betony, Rattlesnake weed, Indian Artichoke, Skullcap -considered a weed, it is found on the } \\
\text { coastal plain from Virginia to south Florida, west to Texas. Flourishes in open habitats and on well to poorly } \\
\text { drained soils. White-segmented tuber roots gave it the name "rattlesnake weed". Racemes with white to } \\
\text { pale pink flowers. } \\
\text { The tuberous roots are edible and sometimes boiled like peanuts. Use as a food is well noted among } \\
\text { southeast U.S. Indian tribes and settlers of Florida's early history, as well as today by many nature } \\
\text { enthusiasts. }\end{array}$ & $\begin{array}{r}\text { Transportation } \\
\text { Medicinal } \\
\text { Food } \\
\text { Housing } \\
\text { Textiles/Tools } \\
\text { Danger }\end{array}$ & $\begin{array}{l}- \\
- \\
X \\
- \\
-\end{array}$ \\
\hline $\begin{array}{l}\text { Stenandrium dulce (Cav.) Nees; synonomous S. floridanum (Gray) Acanthaceae (Acanthus family) } \\
\text { Stenandrium - low growing plant with a restricted range of south peninsular Florida. The species flourishes } \\
\text { in seasonally wet flatwoods dominated by pines and palmettos. Leaves form a rosette. Rosy-purple flowers } \\
\text { form short spikes. Seeds are covered with hairs that are rough to the touch. } \\
\text { According to Moerman (1998), the plant was used medicinally by Seminoles as a pediatric aid and sedative. } \\
\text { Additionally, dried plants were used as baby charms to ward off bad dreams about scary raccoons and } \\
\text { opossums. }\end{array}$ & $\begin{array}{r}\text { Transportation } \\
\text { Medicinal } \\
\text { Food } \\
\text { Housing } \\
\text { Textiles/Tools } \\
\text { Danger }\end{array}$ & $\begin{array}{l}- \\
X \\
- \\
- \\
- \\
-\end{array}$ \\
\hline $\begin{array}{l}\text { Stillingia sylvatica Gard. } \\
\text { Queens Delight, Queens Root - herbaceous shrub ranging from Florida, to South Carolina, and west to the } \\
\text { Mississippi. Found on poor to moderately drained sandy soils, of drainage ditches, canals, and pine } \\
\text { flatwoods, often in standing water. A single brown, leafy stem, with spike green, yellow, and red flowers. } \\
\text { Uses are not well recorded; some southeast tribes used this plant for treatments of diarrhea, vomiting, and } \\
\text { appetite loss. In the late18th century, the plant was used in the south as a common slave remedy for yaws } \\
\text { (common at the time). Physicians in the 20th century used it widely for venereal disease, until the 1940s. } \\
\text { Modern chemical analysis is lacking. Early works suggest fresh (not dry) matter contains the alkaloid } \\
\text { stillingine, resins, and oils. }\end{array}$ & $\begin{array}{r}\text { Transportation } \\
\text { Medicinal } \\
\text { Food } \\
\text { Housing } \\
\text { Textiles/Tools } \\
\text { Danger }\end{array}$ & $\begin{array}{l}- \\
X \\
- \\
- \\
-\end{array}$ \\
\hline $\begin{array}{l}\text { Taxodiaceae (Bald-Cypress or Redwood family) Plate } 23 . \\
\text { Bald -cypress; Pond-cypress - Cypress trees range from south Florida, north to south Illinois, and } \\
\text { westward to Texas. Many taxonomists now accept (using young shoot morphology) that bald-cypress is a } \\
\text { separate species than pond-cypress is T. ascendens Brong. Often found in standing water, natural ponds } \\
\text { and lakes with sandy bottoms, coastal flats with shallow soils over limestone. The leaves deciduous, small, } \\
\text { and scalelike. } \\
\text { Its use as dugout canoes (some of the earliest modes of transportation for the indigenous and migrating } \\
\text { cultures) made this one of Florida's most important plants. Early Indian groups from the Timucua, Seminole } \\
\text { and Mikosukee used cypress wood for fibers, houses, cooking tools, toys, drums, ox bows, and coffins. A } \\
\text { prized wood and preferred mulch; cutting in the early 1900s diminished most of the old-growth cypress, with } \\
100 \text { year old trees being used for furniture, paneling, shingles, water tanks, and beehives. Harvesting has } \\
\text { doubled in Florida from 1980-1995; exceeding all other U.S. states combined (Mattus, 1999) and warrants } \\
\text { concern. }\end{array}$ & $\begin{array}{r}\text { Transportation } \\
\text { Medicinal } \\
\text { Food } \\
\text { Housing } \\
\text { Textiles/Tools } \\
\text { Danger }\end{array}$ & $\begin{array}{l}X \\
- \\
X \\
X \\
X \\
-\end{array}$ \\
\hline
\end{tabular}


Table 3. Fifty Common Native Florida Plants and their Ethnobotanical Uses.

\begin{tabular}{|c|c|c|}
\hline $\begin{array}{l}\text { Tillandsia usneoides L. } \\
\text { Spanish Moss, Old Mans Beard - usually epiphytic plant with reduced to absent stems. Found mostly in } \\
\text { tropical to temperate Americas. Hangs in the trees of hammocks and swamps of the southeast coastal } \\
\text { plains. } \\
\text { Many U.S. Indian tribes used the moss while cooking to absorb unwanted liquids, for bedding, magically to } \\
\text { rub on newborn babies heads for curly hair and for tanning hides. One legend tells of the Spanish explorer, } \\
\text { Gorez Gorez, a bearded ruffian who traded goods for a beautiful Indian maiden. The sight of the Spaniard } \\
\text { frightened the girl, and she ran away. Gorez chased her, climbing after her to the top of a tree. The maiden } \\
\text { escaped, but Gorez's beard became entangled in the tree branches. There he died, but we can still see his } \\
\text { "graybeard" hanging on trees throughout the low country. } \\
\text { Colonial pickers harvested moss with long poles during the winter. The harvest hung for a many months to } \\
\text { cure in a moss yard. Curing loosened the outer gray scales making it ready for commercial ginning. The } \\
\text { black filament core became stuffing for early automobile cushions, and mattresses. Mills operated in Florida } \\
\text { and Louisiana, ginning from } 1900 \text { until } 1975 \text {, when synthetic fibers replaced natural. As of } 1996 \text {, moss was } \\
\text { still brought to markets in Tampa, Florida, mainly for the arts-and-crafts trade. In the past, doctors } \\
\text { prescribed medicines from the moss to treat diabetes. One of the first successful environmental legal cases } \\
\text { involved Florida ranchers suing the mining industry. After a storm, Spanish moss falls to the ground, and } \\
\text { cattle eat it for nutrition, however, the cattle were losing teeth. The moss absorbs many pollutants; one of } \\
\text { these is Fluorine, resulting in fluorine toxicity, a form of tooth decay. One of the by-products of phosphate } \\
\text { mining (throughout Florida) is fluorine. }\end{array}$ & $\begin{array}{r}\text { Transportation } \\
\text { Medicinal } \\
\text { Food } \\
\text { Housing } \\
\text { Textiles/Tools } \\
\text { Danger }\end{array}$ & $\begin{array}{l}- \\
x \\
x \\
- \\
x\end{array}$ \\
\hline $\begin{array}{l}\text { Typhaceae (Cattail family) } \\
\text { Commo spp. } \\
\text { rhizamatous herbs found practically worldwide. Common in brackish or freshwater marshes, shallow water, } \\
\text { ditches, ponds, slow rivers and streams. In Florida, we have } 4-5 \text { recognized species. The leaves are long, } \\
\text { stiff, and sword-like. Stems are topped with yellow (male flowers), forming a cylinder, and green turning } \\
\text { brown sausage-like (female) flowers below. } \\
\text { The two most widely distributed and employed are T. latifolia L., and T. angustifolia L., primarily as food, but } \\
\text { also as medicine, and textiles. Recipes describe the asparagus quality of the shoots, and quality pancake } \\
\text { flower obtained from the pollen. Medical uses are primarily from Native American citations, and only later, by } \\
\text { settlers. Frequent uses are as dermatological aids, such as treatments for abrasions, burns, and chaffing in } \\
\text { babies. Other uses are woven mats, roof thatching, toy making and textiles. The pulp may exude rayon type } \\
\text { compounds. } \\
\text { CAUTION plants are not harmful, but are nitrogen fixers and absorb atmospheric and soil pollutants. }\end{array}$ & $\begin{array}{r}\text { Transportation } \\
\text { Medicinal } \\
\text { Food } \\
\text { Housing } \\
\text { Textiles/Tools } \\
\text { Danger }\end{array}$ & $\begin{array}{l}- \\
- \\
x \\
X \\
X \\
-\end{array}$ \\
\hline $\begin{array}{l}\text { Verbesina virginica L. Compositae (Sunflower family) } \\
\text { White Crownbeard, Frost-weed - perennial herb with leafy stems, ranging throughout Florida and north } \\
\text { through Virginia and Tennessee, west to Missouri, and Kansas. Common on non-acidic (alkaline) soils of } \\
\text { woodlands, meadows, wet hammocks, stream/marsh banks; and coastal shell middens. White ray flowers } \\
\text { or disc flowers. Fruits (achene) with straw colored wings. } \\
\text { According to Moerman (1998), Seminoles used the leaves medicinally for bear sickness (fever, headache, } \\
\text { constipation). Root bark was used to induce vomiting. This plant had many uses, including treating eye } \\
\text { diseases. }\end{array}$ & $\begin{array}{r}\text { Transportation } \\
\text { Medicinal } \\
\text { Food } \\
\text { Housing } \\
\text { Textiles/Tools } \\
\text { Danger }\end{array}$ & \\
\hline $\begin{array}{l}\text { Vitis rotundifolia Michx. } \\
\text { Muscadine Grape, Scuppernong - vine found throughout Florida, Oklahoma, and east Texas, scattered } \\
\text { in Delaware, Kentucky, and Indiana. Found in diverse sites, well drained to poorly drained and sometimes } \\
\text { flooded soils, of both upland and bottomlands. Green flower panicles and fleshy purple, black, bronze, } \\
\text { bunches of fruit. } \\
\text { Most species of Vitis sp. have edible berries. Relative of the plants are used to make Merlots, Cabernets, } \\
\text { and Zinfandel wines. Florida supermarkets have Muscadine wine or juices. Long stems were used to make } \\
\text { a deer snare by the Seminole Indians who also ate the fruit and traded them with pioneers (Moerman, 1998). }\end{array}$ & $\begin{array}{r}\text { Transportation } \\
\text { Medicinal } \\
\text { Food } \\
\text { Housing } \\
\text { Textiles/Tools } \\
\text { Danger }\end{array}$ & \\
\hline
\end{tabular}


Table 3. Fifty Common Native Florida Plants and their Ethnobotanical Uses.

\begin{tabular}{|c|c|c|}
\hline $\begin{array}{l}\text { Ximenia americana L. Olacaceae (Ximenia family) } \\
\text { Tallow-wood, Hog-plum - root parasitic shrub, or sprawling shrub, found in West Indies, and Florida. } \\
\text { Common to well drained soils found in pineland and scrub hammocks. Flowers stalks are small, fragrant, } \\
\text { and cream colored, with two bands of stiff hairs, from base to tips. Fruit is a yellow fleshy drupe. } \\
\text { The fruits are edible. Seminoles used the bark in a body wash to reduce deer sickness (painful limbs) and a } \\
\text { mouthwash from the roots to treat sore gums (Moerman, 1998). }\end{array}$ & $\begin{array}{r}\text { Transportation } \\
\text { Medicinal } \\
\text { Food } \\
\text { Housing } \\
\text { Textiles/Tools } \\
\text { Danger }\end{array}$ & 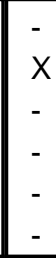 \\
\hline $\begin{array}{l}\text { Zamia pumila L. } \\
\text { Coontie - one of Florida's oldest plants (Cycads - } 200 \text { million years old); it is low and palm-like or fern-like, } \\
\text { with a subterranean stem, which is rich in starch. This plant is widely distributed throughout Florida and } \\
\text { among the Caribbean Islands. Often found in well-drained shallow sandy to sandy - loamy soils, usually } \\
\text { overlying limestone, in scrub, pine, deciduous forests; coastal shell mounds. Male and female plants } \\
\text { produce cones. } \\
\text { Coontie has a long and widespread use as a food among Florida Indian peoples. A flour base called } \\
\text { "sago" or "sofkee" is prepared from the roots, after washing or boiling has removed the poison cycasin. } \\
\text { The caterpillar of the endangered butterfly Atala Hairstreak (Eaumaeus atal florida) is believed to only feed } \\
\text { on Zamia. } \\
\text { CAUTION if eaten may be harmful due to the toxin cycasin, must be processed correctly. }\end{array}$ & $\begin{array}{r}\text { Transportation } \\
\text { Medicinal } \\
\text { Food } \\
\text { Housing } \\
\text { Textiles/Tools } \\
\text { Danger }\end{array}$ & 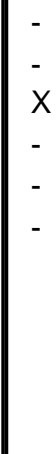 \\
\hline
\end{tabular}

